\title{
Morphometry and spatial distribution of glacial cirques in the Western Fuegian Andes of Argentina, southernmost South America
}

\author{
*Lucas Oliva ${ }^{1}$, Marcela A. Cioccale ${ }^{2}$, Jorge O. Rabassa ${ }^{3}$
}

\author{
${ }^{1}$ Doctorado en Ciencias Geológicas, Facultad de Ciencias Exactas, Físicas y Naturales, Universidad Nacional de Córdoba, Av. Vélez \\ Sarsfield 1611, X5016GCA Córdoba, Argentina \\ olivalucas@hotmail.com \\ 2 Departamento de Geología Aplicada, Facultad de Ciencias Exactas, Físicas y Naturales, Universidad Nacional de Córdoba, \\ Av. Vélez Sarsfield 1611, X5016GCA Córdoba, Argentina. \\ a.cioccale@unc.edu.ar \\ 3 Centro Austral de Investigaciones Cientificas (CADIC), CONICET, Bernardo Houssay 200, Ushuaia, Argentina. \\ jrabassa@gmail.com \\ *Corresponding author: olivalucas@hotmail.com
}

\begin{abstract}
Glacial cirques comprise a distinctive element of relief in alpine landscapes, and their morphometry, distribution and spatial arrangement are generally linked to morphoclimatic factors. This study provides an analysis of morphometric characteristics, floor altitude, aspect and distribution of 251 first-order and 99 "inner" cirques with regard to environmental agents in a selected alpine-type area of the southwestern Fuegian Andes, in Southern Argentina. Parametric variables were extracted and quantified from satellite images and a Digital Elevation Model, and integrated to a Geographical Information System for their systematization and processing. Significant associations were identified between the different geometric and spatial parameters evaluated. Variability in cirque morphometry along the study area suggests that their evolution was regulated to a large degree by glacial dynamics related to Beagle palaeoglacier activity, and by the W-E topographic gradient of the mountain section. The record indicates that most cirques in the Fuegian Andes have undergone allometric enlargement in the three dimensions (i.e., lesser vertical erosion compared to walls' horizontal expansion), with local variations in size and shape controlled by ice residence time, aspect and altitude, whereas geological structure is supposed to have affected cirque formation along the entire mountain chain. Cirque azimuth potentially responds to the combined influence of climate (solar radiation and westerly winds), structure (pervasive faulting and rock bedding) and topography in their development. In particular, dominance of southeasterly aspects is interpreted as a consequence of a relatively cloud-free atmosphere and aridity during past glacial periods in the region, consistently with published evidence. The absence of aspect-related variation in cirque floor altitude is considered to indicate incidence of extensive glaciations in the area (i.e., mostly ice-sheet conditions, with mountain peaks far above the regional equilibrium line altitude or ELA), as well as formation of younger, lower cirques during successive cold periods of different intensity. Occurrence of "inner" cirques inside larger (preexisting) cirques is thought to reflect a temporary positioning of the ELA just above the floor of the container cirque, permitting short-lived, small cirque-type glaciers to develop along structural bedrock weaknesses.
\end{abstract}


RESUMEN. Morfometría y distribución espacial de circos glaciarios en los Andes Fueguinos Occidentales de Argentina, extremo sur de Sudamérica. Los circos glaciarios comprenden elementos distintivos del relieve en los paisajes alpinos, y su morfometría, distribución y disposición espacial están generalmente vinculadas a los factores morfoclimáticos presentes. Este estudio proporciona un análisis de las características morfométricas, la altura del piso, la orientación y la distribución de 251 circos glaciarios de primer orden y 99 circos interiores, en relación con los agentes ambientales en un área de tipo alpino, seleccionada en los Andes Fueguinos, en el extremo sur de Argentina. Las variables paramétricas escogidas fueron extraídas y cuantificadas a partir de imágenes satelitales y un modelo digital de elevación, y se integraron a un sistema de información geográfica para su organización y procesamiento. Se identificaron asociaciones significativas entre los diferentes parámetros geométricos y espaciales evaluados. La variabilidad observada en la morfometría de los circos a lo largo del área de estudio sugiere que su evolución estuvo regulada en gran medida por la dinámica glaciaria vinculada a la actividad del paleoglaciar Beagle, y por el gradiente topográfico de $\mathrm{O}$ a $\mathrm{E}$ del cordón montañoso. El registro obtenido indica que la mayoría de los circos en los Andes Fueguinos estuvo sujeta a crecimiento alométrico en las tres direcciones (i.e., menor erosión vertical respecto a la expansión horizontal de las paredes), con variaciones locales en su tamaño y forma controlados por el tiempo de ocupación glaciaria, la orientación y la altitud, en tanto que el factor geológico estructural habría afectado el desarrollo de los circos a lo largo de toda la sección estudiada. La orientación de los circos probablemente está reflejando la influencia combinada del clima (radiación solar y vientos del oeste), la estructura geológica (intenso fallamiento y estratificación de la roca de base) y la topografía a lo largo de su evolución. En particular, el predominio de circos expuestos hacia el S y el SE es interpretado como consecuencia de condiciones de aridez (con cielos relativamente despejados) durante los diferentes periodos glaciarios de la región, como ya ha sido propuesto en otros estudios. Se considera que la aparente ausencia de correlación entre la altura del piso y la orientación de estas geoformas es indicativa de glaciaciones intensas en el área (i.e., picos montañosos muy por encima de la línea de equilibrio glaciario [ELA, por sus siglas en inglés] regional), así como de la formación de circos más jóvenes y de menor cota durante sucesivos eventos fríos de diferente magnitud. La presencia de circos "interiores" dentro de circos previos de mayores dimensiones indicaría una estabilización temporaria de la ELA apenas por encima del piso del circo hospedante, lo cual habría permitido el desarrollo de pequeños glaciares de circo a lo largo de las debilidades estructurales del sustrato rocoso.

Palabras clave: Circos glaciarios, Alometría, Distribución de circos, Andes Fueguinos, Tierra del Fuego.

\section{Introduction}

Investigations in glacial erosion processes are of capital importance in understanding the connection between climate and topography. Given their extensive and continuous areal coverage in mountainous regions, and the possibility of tracing them using remote sensing, glacial cirques comprise valuable geoindicators of past global environmental changes (e.g., Barr and Spagnolo, 2015). Glacial cirques are theatre-shaped depressions, typically developed at high topographic settings in glacial landscapes by the erosive action of mountain glaciers (Evans and Cox, 1995; Barr and Spagnolo, 2015). Morphologically, they consist of semi-circular hollows opened downhill, and bounded upstream by the convex crest of a steep headwall, which is arcuate in plan around a more gently-sloping floor (Evans and Cox, 1974). Their dimensions range from hundreds of meters to a few kilometres, and they are usually connected with valleys through rocky thresholds. Cirques generally originate from the glacierization of an already indented topography, where the ice occupied pre-existing irregularities, previously generated by fluvial processes or landslides (Evans, 2006a). Cirques can be situated at the headwaters of valleys (valley-head cirques) or at their flanks (valley-side cirques) (sensu Mîndrescu and Evans, 2014). Cirque complexes (nested cirques) are usually a common feature in ranges which rose well above former snowlines, and consist of "compound" cirques containing one or more "inner" cirques. These inner cirques correspond to smaller cirques of nivation hollow aspect, originated within compound cirques by wall erosion, usually at higher altitudes (Simoni, 2011). To be considered as "inner", a cirque must have a distinct floor, separated from the host cirque floor (and from other "inner" cirque floors) by a steep slope, in a way that all contained ice flowed into a compound cirque. In addition, each compound cirque must have a section of headwall apart from those belonging to its contained inner cirques (Evans and Cox, 1974; Mîndrescu and Evans, 2014).

Because of their reduced dimensions and volume, cirque glaciers are extremely responsive to regional climate variability (mainly to summer temperature and mean annual precipitation), and after glaciation, abandoned cirques remain as certain geomorphic 
proxies of past climate conditions (e.g., Gordon, 1977; Aniya and Welch, 1981; Evans, 2006a; Delmas et al., 2014; Barr and Spagnolo, 2015; Ipsen et al., 2018). Given that cirque glaciers are formed and maintain their activity around the equilibrium line altitude (ELA), their floor elevation can be considered as a proxy of the average Quaternary ELA (e.g., Mitchell and Montgomery, 2006; Foster et al., 2008; Mitchell and Humpries, 2015), which has been linked to regional climatic context (e.g., Flint, 1957; Porter, 1964; Embleton and King, 1975; Williams, 1975). The distribution, morphometry and aspect of cirques are affected by the intensity, duration and extent of glaciation, which in turn depend, among other factors, on climate and topography (Barr and Spagnolo, 2013).

In recent decades, numerous studies about glacial cirques have highlighted the control exerted by climate and geology on their morphometric attributes. Most of them emphasized the influence of the climatic factor on cirque distribution, mainly on their azimuth (e.g., Trenhaile, 1976; Olyphant, 1977; Křížek and Mida, 2013; Mîndrescu and Evans, 2014). Other authors observed that cirque morphometry correlates with topographic characteristics, such as altitude, gradient and slope aspect (e.g., Evans, 1972, 1999; Kř́žek and Mida, 2013). The incidence of lithology and structure on cirque morphology and dimensions has been widely recognized (e.g., Haynes, 1968; Alonso, 1994; Evans, 1994; Sauchyn et al., 1998; Delmas et al., 2014). Nevertheless, some studies stated that geology has little relevance in determining morphometric properties of cirques (Evans and Cox, 1995; García-Ruiz et al., 2000; De Blasio, 2002; Barr and Spagnolo, 2013). In these cases, the development of cirque shape would be responding to a morphostructural predisposition of relief (preferential snow accumulation areas). Attempts have also been made to establish a proportionality between morphometry and the estimated age of cirques, indicating that morphological differences between cirques could be reflecting diverse stages in their development or a distinct growth rate, rather than differences in environmental factors (Haynes, 1998; Brook et al., 2006; Bennett and Glasser, 2011).

Cirques are widely distributed all along the $7,000 \mathrm{~km}$ of the Andean Cordillera, offering an inestimable opportunity to compare morphometric and distribution properties of cirques present in many different topoclimatic regions. From the Sierra Nevada de Mérida, in Venezuela, to the Fuegian Andes, cirques should have been modelled by glaciers with contrasted activities due to differences in temperature and regional moisture patterns (and thus with different erosive behavior), as shown by modern glaciers from the tropical, the dry subtropical and the temperate mid-latitude Andes (Rodbell et al., 2009). This paper presents an inventory of the glacial cirques in the southwestern sector of the Argentine Fuegian Andes (see boxed area in figure 1A) and provides landformprocess evidence from their quantitative analysis. In the global scene, Tierra del Fuego comprises the continental territory closest to Antarctica, receiving the full impact of the Antarctic Circumpolar Current (e.g., Orsi et al., 1995), and therefore operates as an observatory of the Subantarctic Oceanic Belt, in the confluence of the Atlantic and Pacific Oceans. Given this situation, the study of glaciations in the Fuegian Andes can certainly provide a linkage between the climatic history of the Antarctic Peninsula and the southernmost portion of South America. In particular, the area selected for this investigation represents a unique setting to evaluate cirques developed under the influence of both alpine and ice sheet glacial contexts, since this zone was covered from the west by the southernmost present icefield of the Andes Range during maximum cold phases of the Pleistocene (Rabassa et al., 2000). Under this comprehension, the objective of this publication is to assess the relationship of cirque morphometry and distribution with geological (mainly structure) and morphoclimatic dominant conditions. In so doing, it is attempted to contribute to the understanding of the magnitude of glaciations in southernmost South America and, particularly, to the knowledge of the palaeoglacial model proposed for the Beagle Channel area (e.g., Rabassa et al., 2000).

\section{Previous cirque investigations}

Studies about glacial cirques are plentiful in the Northern Hemisphere, mainly in North America and Europe (see summaries in Evans, 1977 and Barr and Spagnolo, 2015). The Southern Hemisphere, on the other hand, has scarce previous works, and only a few isolated studies have focused on cirque distribution and/or their morphometric attributes: Clapperton (1971) in Islas Malvinas (Falkland Islands), Aniya and Welch (1981) in Antarctica, Brook et al. (2006) in New Zealand, Ponce and Rabassa (2012) in Isla 

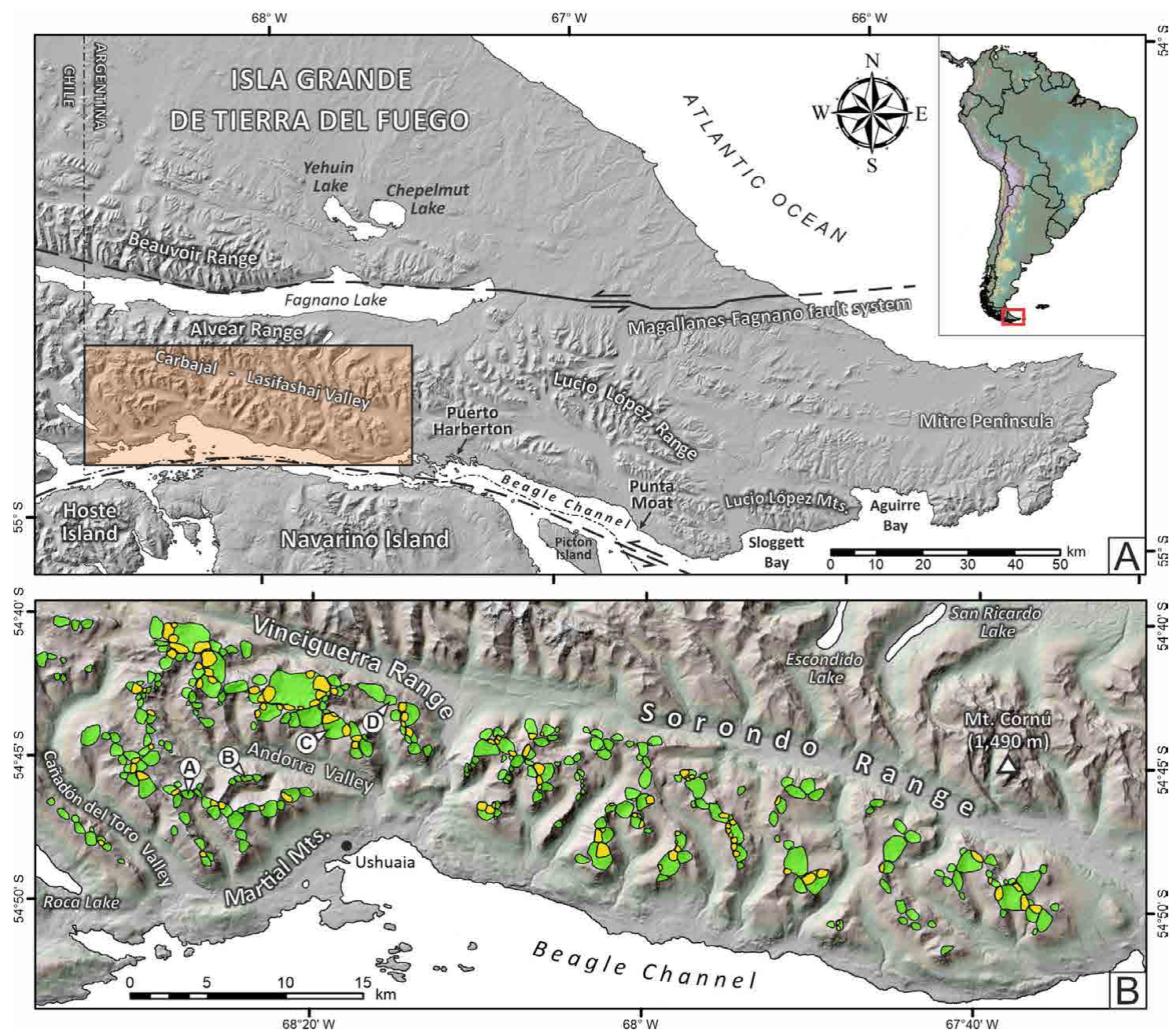

FIG. 1. A. Map of the southern part of argentine Tierra del Fuego, including the location of the study area. The two major geological structures that affect the region are delineated: the Magallanes-Fagnano and the Beagle Channel fault systems. B. Area of the Fuegian Andes where morphometric characteristics of cirques were analysed (green polygons: first-order cirques; yellow: inner cirques), showing the mountain ranges and valleys cited in the text. Letters inside white circles correspond to cirques described in figure 5 (Coordinates in Lat/Lon; Projection: UTM; Datum: WGS84).

de los Estados (Staten Island), Argentina, and Araos et al. (2018) in Southern Patagonia $\left(50^{\circ} \mathrm{S}\right)$. In Tierra del Fuego, Coronato (1996) highlighted the incidence of climate and relief structure on the distribution of cirques and present cirque glaciers in a portion of the southwestern Argentine Fuegian Andes. In Martial Glacier cirque $\left(54^{\circ} 47^{\prime} 27^{\prime}\right.$ S- $\left.68^{\circ} 23^{\prime} 43^{\prime} \mathrm{W}\right)$, near the city of Ushuaia (Fig. 1B), Planas et al. (2002) proposed a glacierization scheme since the Last Pleistocene Glaciation from geomorphological analysis of moraine deposits. On the other hand, Strelin and Iturraspe (2007) and Iturraspe et al. (2009) performed glaciological surveys on remaining ice bodies in the cirques of Martial and Vinciguerra (54'43'32.87' S$68^{\circ} 20^{\prime} 10.46^{\prime}$ W) glaciers, respectively. Based on geomorphologic evidence, Coronato et al. (2009) estimated the ice thickness within cirques and hanging valleys that merged the Fagnano palaeoglacier in its central-western (catchment) sector. Iturraspe (2011) provided valuable information about the characteristics and possible evolution of the glaciers of the Argentine Fuegian Andes and Cordillera Darwin (Chile). A preliminary broad-scale geomorphological mapping $(1: 50,000)$ including some of the cirques of the study 
area was presented by Glasser et al. (2008), and more recently Menounos et al. (2013) supplied an absolute chronology of glacial fluctuations since the Last Glacial Maximum in southwestern Argentine Fuegian Andes from the study of glaciated bedrock and deposits within and adjacent to glacial cirques.

\section{Study area}

\subsection{Topographic and geological setting}

The Fuegian Andes represent the southernmost segment of the Andes Range, including the Fuegian Archipelago and the southern portion of the Isla Grande de Tierra del Fuego, at the southern end of South America (Fig. 1A). At this latitude, the N-S direction of the Andes changes to E-W due to the continuous movement of the Scotia plate eastwards since the Early Tertiary (Rabassa et al., 2005). In Chilean territory, the Fuegian Andes receive the name of Cordillera Darwin, with its maximum altitude at Mount Darwin, 2,440 m above sea level (a.s.1.), comprising mainly the Fuegian Archipelago. On the Argentine side (maximum altitude: Mount Cornú, 1,490 m a.s.1.) the Fuegian Andes extend up to the eastern end of the island, continuing in Isla de los Estados beyond the $\sim 30 \mathrm{~km}$-wide Le Maire Strait. This mountainous section consists of several mountain ranges predominantly oriented WNWESE, separated by structural valleys, with maximum elevations descending from $\mathrm{W}$ to $\mathrm{E}$ from 1,100$1,400 \mathrm{~m}$ a.s.1. to $c a .500 \mathrm{~m}$ a.s.1.

The stratigraphic rock sequences that comprise the Fuegian Andes have been affected by a series of contrasting tectonic regimes, represented by extension during the Upper Jurassic-Lower Cretaceous, compression in the Upper Cretaceous-Paleogene, and transcurrence during the Cenozoic (Katz, 1972; Dalziel et al., 1974; Kohn et al., 1995). The structure is characterized by a large E-W oriented complex fault system, with deviations to the NE and SE, and thrust sheets facing $\mathrm{N}$, associated with dynamic metamorphism older than the Late Cretaceous (Caminos, 1980; Ramos, 1999). On the southern part of the Fuegian Archipelago, the MagallanesFagnano Fault Zone (MFFZ), which defines the boundary between the South American (to the N) and Scotia (to the S) plates, was activated after the compressive phase, in the late Miocene $(\sim 10 \mathrm{Ma})$ (Torres-Carbonell et al., 2014), and is associated with small pull-apart basins and profuse strike-slip structures (Ghiglione, 2002; Ghiglione and Ramos, 2005). Both tectonic plates record a lateral displacement at a relative rate of $6.6 \pm 1.3 \mathrm{~mm} / \mathrm{yr}$ (Smalley et al., 2003). The Fuegian Andes also show evidence of counterclockwise crustal rotation and strike-slip faulting along the Beagle Channel Fault Zone (BCFZ) since the Late Cretaceous (Cunningham, 1994, 1995). This deformation produced the pervasive strikeslip faulting present through the basement domain (Cunningham, 1994; Ghiglione and Cristallini, 2007) and is responsible for the exhumation of the Cordillera Darwin metamorphic complex (Nelson, 1982; Kohn et al., 1995). The northern shore of the Beagle Channel's central segment is characterized by several E-W oriented glacial valleys, parallel to the channel, which are interspersed with a series of oblique NW-SE trending lineaments that extend across the mountain belt (Bran et al., 2018) (Fig. 2). These authors inferred an extensional control over the oblique transverse lineaments in the area, and suggested they might be the result of inherited structural corridors between two sub parallel E-W fault systems, reactivated by transtensional deformation in times (according to Torres-Carbonell et al., 2014) not older than the late Miocene.

The area surveyed in this paper includes the mountainous segment from the international border with Chile and along the northern coast of Beagle Channel, in the SW sector of the Fuegian Andes, and is formed by Martial Mountains area and Vinciguerra Range to the west, and Sorondo Range to the east, all of them separated from each other by large structural valleys (Fig. 1). This section, that follows the general direction and topographic gradient of the Fuegian Andes, extends over $73 \mathrm{~km}$ and occupies a total area -bounded along the foot of the mountains- of $919.7 \mathrm{~km}^{2}$. It is primarily composed of two lithological types in similar proportions, whose contact, defined by a tectonic thrust, is oriented approximately along the chain axis (Fig. 2). The northern portion is composed almost entirely of intensely deformed marine volcanic and sedimentary rocks (schists, carbonaceous slates, sandstones, tuffs, breccias, rhyolite and basalts) of Upper Jurassic age (the Lemaire Formation; Borrello, 1969), whereas the flanks facing south are formed by strongly folded marine meta-sedimentary rocks (dark slates, tuffs, and sandstones) of Lower Cretaceous age (the Yahgan Formation; Kranck, 1932). In the SW part, covering 


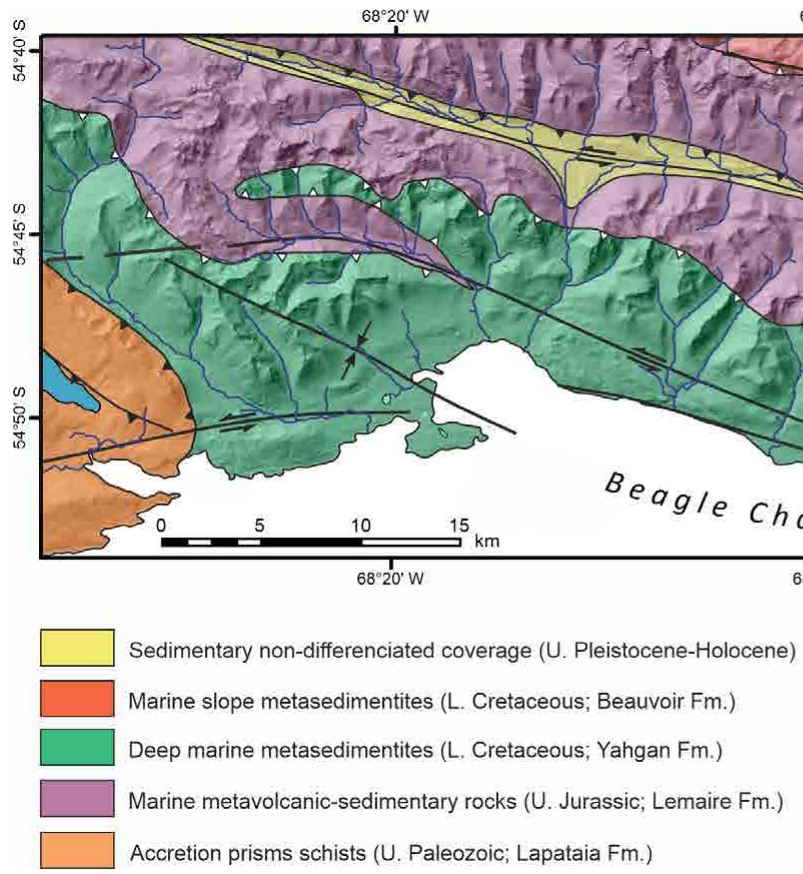

$68^{\circ} \mathrm{W}$

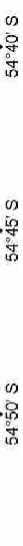

FIG. 2. Schematic geologic map of the study area. Lithological units after Olivero and Malumián (2008). Tectonic context showing the main structural features is based on Menichetti et al. (2008), Esteban et al. (2014), Torres Carbonell et al. (2014) and Bran et al. (2018).

a smaller area, accretion prisms schists (phyllites and amphibolites) of Upper Palaeozoic age emerge (the Lapataia Formation; Caminos et al., 1981). The Mesozoic sequence was partially covered by fluvial and glaciofluvial deposits in the inter-montane glacial valleys and by colluvial deposits and Late Glacial or Neoglacial moraines within some of the cirques.

The morphology of this range results from the combined action of the tectonic deformation that still affects the region, and glacial erosion produced during the successive Pleistocene cold events, mainly the Last Glaciation ( $c a .85$ to 10 ka B.P.; Rabassa, 2008). Glacial cirques constitute a dominant geomorphological feature in the area, delimiting almost the totality of ridges and mountain peaks. A wide network of single glacial valleys crosses the mountain chain, transversely to major longitudinal WNW-ESE trending troughs, tributaries of the Beagle Channel. Hanging valleys, arêtes, horns and truncated spurs are also conspicuous elements in the landscape constitution of this sector (Coronato, 1995, 1996; Planas et al., 2002; Coronato et al., 2009). Latero-frontal morainic arcs are observable in cirques (Planas et al., 2002; Menounos et al., 2013) and in tributary and hanging valleys (Coronato, 1990, 1993, 1995), but they are covered by the forest in the lowlands (Rabassa et al., 2000) (timberline is located at $c a$. 500-700 m a.s.1.; Puigdefábregas et al., 1988; Strelin and Iturraspe, 2007). Cryogenic landforms (nivation hollows, subnival clast pavements, protalus ramparts, debris lobes, patterned ground and cryo-ejected clasts) abound in the higher portions of mountains (Valcárcel-Díaz et al., 2006), and the presence of small rock glaciers is frequent within some cirques in the western Fuegian Andes (Vega, 2004; González et al., 2007).

\subsection{Climate}

The present regional climate of Tierra del Fuego is significantly influenced by the provenance of cold and wet air masses from the Pacific Ocean polar front (Tuhkanen, 1992). When cyclones reach the mountainous areas of southern Tierra del Fuego, they produce a maritime, cold, wet and windy weather giving a mean annual air temperature of 
$5.5{ }^{\circ} \mathrm{C}$ (Strelin and Iturraspe, 2007). Prevailing winds from the SW and S provide moisture to the region and generate orographic precipitations with a strong gradient from the SW, with $600 \mathrm{~mm} /$ year, to the NE, with less than $300 \mathrm{~mm} /$ year (Rabassa et al., 2006). The southern portion of the island is protected from dominant westerly winds by the Cordillera Darwin and the higher mountains of Hoste and Navarino islands, in Chile (Strelin and Iturraspe, 2007). The Fuegian Andes show a general gradient in precipitation from $\mathrm{W}$ to $\mathrm{E}$, although they reveal an increment from the eastern mouth of the Beagle Channel to the eastern extreme of the Isla Grande de Tierra del Fuego and Isla de los Estados (around 1,500 mm/year in the latter; Dudley and Crow, 1983) due to the entrance of oceanic wet air masses from the south, without the shielding of the aforementioned mountain barriers (Rabassa et al., 2006). Maximum precipitation occurs in the higher portion of the Fuegian Andes, near the border with Chile and south of Fagnano Lake (Rabassa et al., 2006) (Fig. 3). In the Chilean sector, the Fuegian Andes are covered by the mountain icefield of Cordillera Darwin, which has outlet glaciers reaching present sea level (the ELA in Cordillera Darwin is located at $c a$. 600-700 $\mathrm{m}$ a.s.l.; Iturraspe, 2011). In Argentine territory, on the other hand, present climate only permit the development of small ice masses $\left(<1 \mathrm{~km}^{2}\right)$ above ca. $940 \mathrm{~m}$ a.s.l. (Zalazar et al., 2017) which, with the current position of the ELA at around 1,100 m a.s.l. (Rabassa and Clapperton, 1990; Strelin and Iturraspe, 2007; Coronato et al., 2009), are shrinking rapidly due to global and regional warming (Strelin and Iturraspe, 2007; Iturraspe et al., 2009; Iturraspe, 2011).

\subsection{Glacial history}

Most of the Isla Grande de Tierra del Fuego, and perhaps the entire island, was occupied by extensive glaciers in the early Pleistocene, during the Great Patagonian Glaciation (GPG, ca. 1.1 Ma B.P.; Mercer, 1976; Ton-That et al., 1999; Singer et al., 2004), and then was partially covered by ice repeatedly throughout the middle and late Pleistocene (Rabassa et al., 2000). Evidence of at least five glaciations (starting with the GPG) has been documented in the northern part of the Isla Grande de Tierra del Fuego (Meglioli, 1992; Porter et al., 1992; Clapperton et al., 1995), the oldest three even extending off-shore to culminate in the present Atlantic submarine platform (Porter, 1990; Meglioli et al., 1990; Isla and Schnack, 1995). Nevertheless, only the last two cold events (i.e., the last Middle Pleistocene Glaciation or post-GPG III [Coronato et al., 2004], and the Last Glaciation) were recognized in the Fuegian Andes setting (Rabassa et al., 1990a; Meglioli, 1992). Ice coverage in this area would have had different extent and volume in each of the known regional glacial advances, reaching piedmont sectors and maritime waters in several opportunities, and receding to the summits and high lands in the interglacial stages (Rabassa et $a l ., 2000$ ). During the Last Glacial Maximum (LGM, ca. 24-25 ka B.P. in southernmost Patagonia; e.g., McCulloch et al., 2005; Kaplan et al., 2008; Coronato et al., 2008), the Fuegian Andes received glacier ice

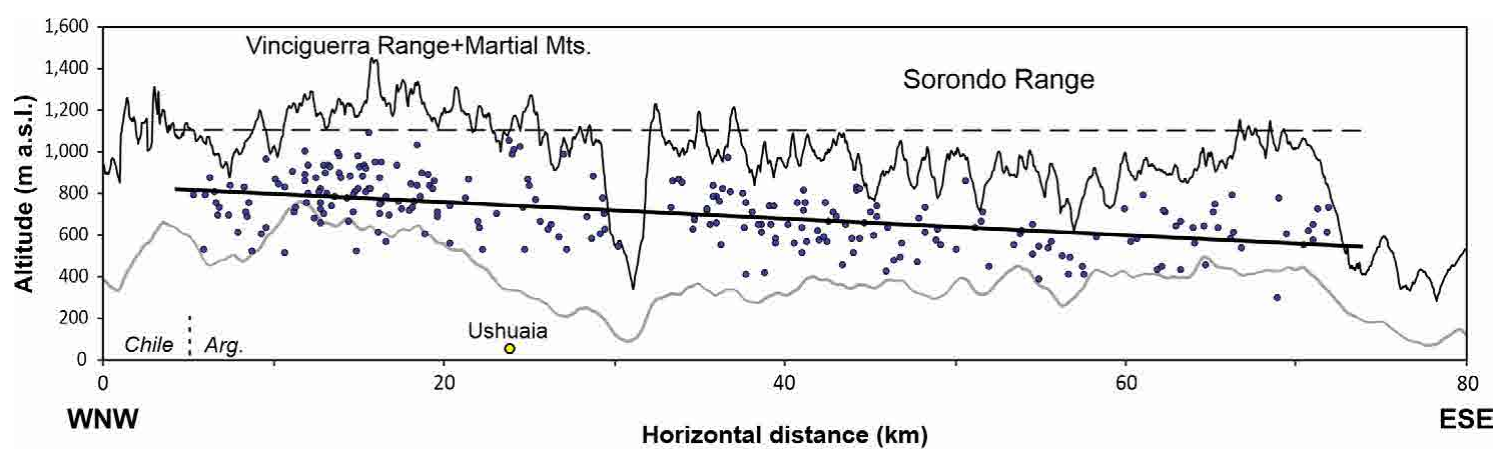

FIG. 3. Swath topographic profile of the study area. The black profile line corresponds to the maximum elevations, and the gray line was confectioned with the mean elevations. Cirques (blue dots) were plotted according their floor altitude, and the black solid trend line built from them constitute an approximation to the composite Quaternary ELA (Flint, 1957; Porter, 1975). The dashed line illustrates the present-day ELA estimated for the area, based on Coronato (1996), Coronato et al. (2009) and Iturraspe (2011). 
from the Cordillera Darwin icefield, from which outlet glaciers were channeled by large structural valleys constituting the main lobes that occupied the Magellan Strait and Bahía Inútil-San Sebastián depression to the north, and Fagnano Lake basin and the Beagle Channel to the south, in the Andean region (Rabassa et al., 2000). Terminal moraines representing the post-GPG III were recognized in Bahía Sloggett, in the southern coast of Tierra del Fuego, ca. $125 \mathrm{~km}$ east of Ushuaia (Rabassa et al., 1996) (Fig. 1A), and in the northeastern sector of Fagnano Lake ("Lago Chepelmut drift"; Meglioli, 1992; Río Fuego valley; Coronato et al., 2008) and presumably along its southern coast ("Río Valdez drift"; Meglioli, 1992), whereas in the surveyed area (as in the rest of the southern Fuegian Andes) only the LGM geomorphological evidence has been documented (Rabassa et al., 1990a, 2000; Coronato, 1993, 1995, 1996). During this maximum ice expansion, the front of the Beagle palaeoglacier would have been located close to Punta Moat, at the eastern mouth of the channel, $c a .100 \mathrm{~km}$ east of Ushuaia (Rabassa and Clapperton, 1990) (Fig. 1A). Lateral moraine complexes attributed to the LGM (Caldenius, 1932) were recognized at $150 \mathrm{~m}$ a.s.1., $10 \mathrm{~km}$ westwards Punta Moat, providing a preliminary estimated value of the LGM-ELA for the area (Rabassa et al., 1990b). The exposed surface of Tierra del Fuego is supposed to have been at least twice the present one in LGM times due to lowering of sea level (around 120 and $130 \mathrm{~m}$ below present sea level; Fleming et al., 1998; Thompson and Goldstein, 2006), with marine Atlantic coast displaced around $130 \mathrm{~km}$ eastwards (Ponce et al., 2011a). This situation would have produced more continental climatic conditions than the current ones (Rabassa et al., 1992, 2000; Ponce et al., 2011b). By then, ice bodies in the studied area were probably not connected to the Cordillera Darwin icefield in the form of a continuous, uniform mantle, but would have constituted an extensive and thick glacial mass interrupted by rocky peaks and high ridges (Coronato, 1995; Rabassa et al., 2000; Coronato et al., 2009). The main inner troughs along Beagle Channel's north coast were fully glaciated during the LGM (Rabassa et al., 2000), as were the Fagnano Lake basin (Coronato et al., 2005, 2009) and the Carbajal-Lasifashaj, Andorra and Cañadón del Toro valleys (Rabassa et al., 1990a, 1996; Coronato, 1990, 1993, 1995) (Fig. 1A and B). According to valley location, the ice that filled them would have reached thicknesses of at least 400 to $600 \mathrm{~m}$ (Coronato, 1995; Coronato et al., 1999). During this maximum cold phase, ice volume in tributary valleys was regulated by the dynamics of the Beagle palaeoglacier, which by then is supposed to have reached a minimum of $1,200 \mathrm{~m}$ thick in areas near Ushuaia, burying the surrounding landscape below 500-700 $\mathrm{m}$ a.s.1. (Coronato, 1995), and even penetrating into some of the tributary valleys and cirques (i.e., blocking their glaciers downward flow), as demonstrated by Coronato $(1990,1995)$ in Andorra Valley and by Planas et al. (2002) in Martial Glacier cirque. When they did not cover the highest inner water divides (at about 800-900 m a.s.1.; Coronato, 1995), some ice masses would have merged the main collectors from cirques through short ice tongues (Coronato, 1995; Coronato et al., 2009), although in most cases cirque glaciers probably connected to the glacial tributary network almost directly.

Deglaciation process in the region, coincident with a rapid warming in the high and middle Southern Hemisphere latitudes, started at ca. $18.4 \mathrm{ka}$ BP (Hall et al., 2013), and most glaciers from the Cordillera Darwin icefield were close to their current position as early as ca. $16.5 \mathrm{ka}$ (Hall et al., 2017). In the southwestern Fuegian Andes, alpine areas beyond cirques were ice-free by $c a$. $16.9 \mathrm{ka}$ (Menounos et $a l ., 2013)$, and the front of the Beagle ice lobe was already $70 \mathrm{~km}$ west of Ushuaia by $14.8 \mathrm{ka}$ (Hall et al., 2013). Lateglacial advances in this region occurred in coincidence with the Antarctic Cold Reversal (14.5$12.9 \mathrm{ka}$; Jouzel et al., 2001) and the Younger Dryas Stadial (12.9-11.7 ka; Rasmussen et al., 2006; Lowe et al., 2008; Menounos et al., 2013), before glaciers finally receded from lower altitude valleys, allowing glaciolacustrine environments dominate in those sectors (Coronato, 1995; Rabassa et al., 2000). More recently, glaciers readvanced successively during the Holocene (Neoglaciations), depositing several terminal moraines in cirques and high tributary valleys (Coronato, 1995; Rabassa et al., 2000; Planas et al., 2002; Menounos et al., 2013; Ponce et al., 2015). Menounos et al. (2013) identified one or more successive glacier expansions between 7.96-7.34 ka and 5.29-5.05 ka, with glaciers partly filling cirques and hanging valleys to positions only tens of meters downvalley from those of the Little Ice Age (LIA; $<1,000$ cal. yr B.P.). Although no absolute ages are available for the innermost moraines, these authors classified them as LIA deposits based 
on their degree of preservation, proximity to present glaciers, and similarity of their positions to moraines in adjacent areas that have previously been assigned to the LIA (Strelin and Iturraspe, 2007; Strelin et al., 2008; Maurer et al., 2012).

Although there is no definitive agreement about the specific glaciological setting that led to formation of glaciers that eroded the cirques of the Fuegian Andes (Menounos et al., 2013), it is probably that they were occupied by ice in the various Pleistocene cold phases (Rabassa et al., 2000), attaining their current size and morphology throughout the Last Glaciation and during its decay, when glacial coverage begun to diminish ("Individualization" and "Stabilization" stages; $c a .18$ to 14 and 14 to $12 \mathrm{ky} \mathrm{BP,} \mathrm{respectively;}$ Coronato, 1995) and tributary valley glaciers acquired a behaviour independent from that of the Beagle palaeoglacier, which in turn was receding from its easternmost frontal position (Rabassa et al., 1990b; Coronato, 1995).

\section{Data and methods}

Cirques were identified and mapped from a Digital Elevation Model (ALOS PALSAR DEM, with a spatial resolution of $12.5 \mathrm{~m}$; Rosenqvist et al., 2007) and high resolution satellite images (Digital Coverage Globe-Google Earth: SPOT Image; spatial resolution of $2.5 \mathrm{~m}$ ) from Google Earth software. Field checking was necessary for ascertaining landscape features lacking precise definition on maps and imagery, as well as lithological and structural properties of bedrock. A series of surface models was derived from the DEM, from which parametric information was obtained (altitudes and mean slope gradient). Cirques were delimited in correspondence to Evans and Cox $(1974,1995)$ criteria for the distinction of the different morphological elements involved (Fig. 4). They were recognized as concave downvalley-opened surfaces of varying depth and gradient, surrounded by an arcuate crest (headwall), generally occupying the headwaters of valleys within high-altitude sectors of drainage basins (Barr and Spagnolo, 2013). The headwall upper limit was defined by following the crestline, which commonly coincides with the main divide, or along breaks in slope with respect to upward topography in case no certain crestline existed. Nevertheless, cirque demarcation involves the issue of determining its boundary with downslope relief, which ideally
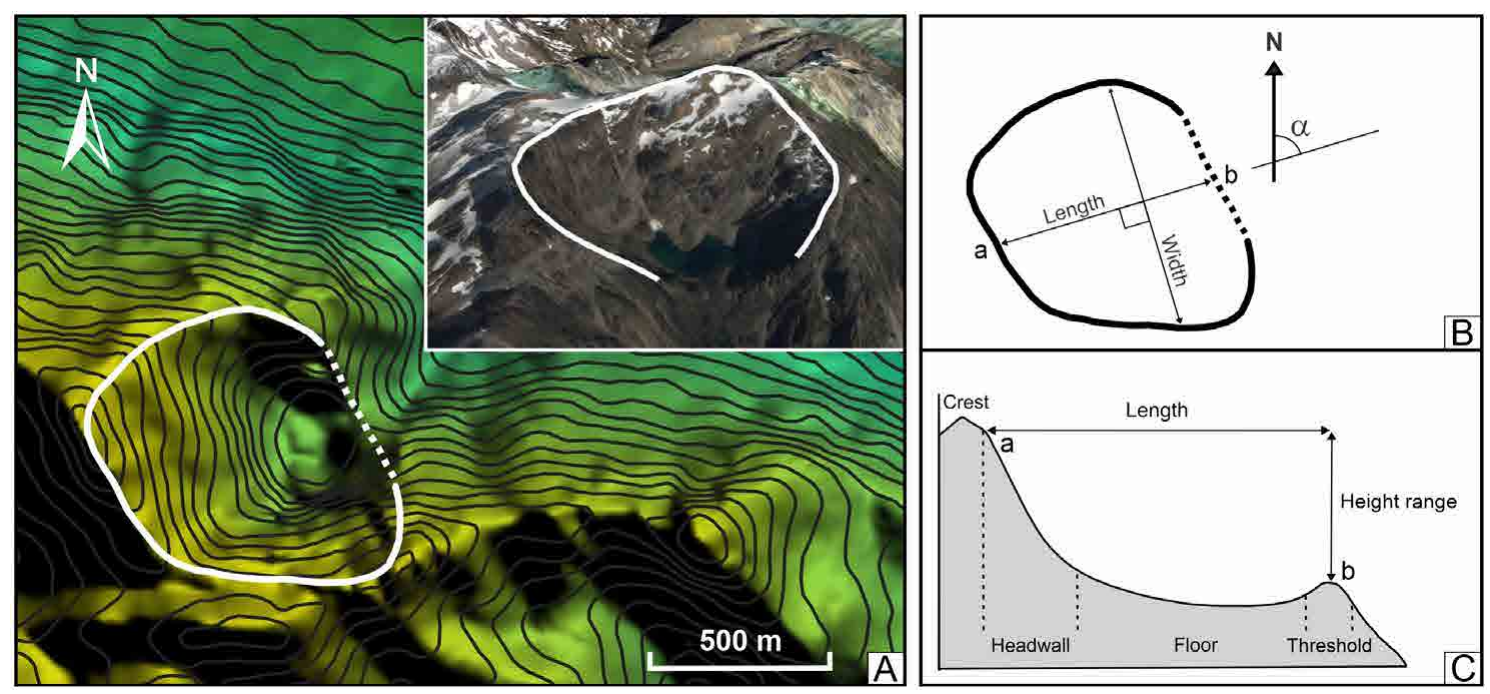

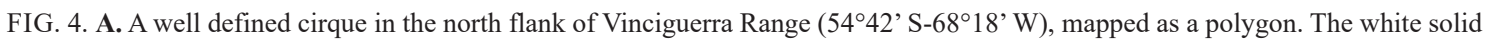
line corresponds to the upper edge of headwall outline, and the dashed stretch represents the threshold, which establish the transition of cirque floor to down-valley, steeper topography. The inset image is a 3D perspective from the east, clearly showing the rounded crest that defines cirque contour (Google Earth image). B. Definition of some of the main variables measured: length (a-b distance; L), width (longest distance perpendicular to L; W) and $\alpha$, the angle between the median axis $\mathrm{L}$ and geographic north. The dashed line represents the threshold. C. Profile view along the cirque maximum gradient line, outlining the distinction between the different morphological features of a cirque. See table 1 for additional morphometric definitions. 
corresponds to the threshold, but that is frequently transitional, sometimes without an evident slope break. This circumstance is common when cirques are situated at valley-head settings, where the floor limit downstream must be established by extending the headwall spurs along both margins. Each cirque was digitized as an enclosed polygon with an individual nomenclature (Fig. 4A and B), and linked to a database with its corresponding parametric information, generated in a Geographical Information System (ArcGIS 10 software). This procedure allowed the confection of a series of maps showing the metric attributes of cirques (height range, length/width ratio, length/height range ratio and floor elevation) that were useful to examine different patterns in morphometry and spatial distribution of cirques. When measuring compound cirque properties, inner cirques were included within them, because their presence does not alter the morphology or dimensions of the former, according to the parameters used in this study. Cirques were analysed in two groups: a) compound and simple cirques, and b) inner cirques (Fig. 1B). In this work we refer to both simple and compound cirques as "first-order cirques" or simply as "cirques".
In order to attain a reliable operational definition, the morphometric variables used in this investigation were defined according to procedures described in previous researches (Aniya and Welch, 1981; Evans and Cox, 1995; Evans, 2006a; Hughes et al., 2007) (Table 1). Apart from these attributes, cirque azimuth (Az) was measured as the outward direction of the median axis (=length) with respect to the geographical north (sensu Evans and Cox, 1995) using a GIS (Fig. 4B). Eight aspect intervals were established: $\mathrm{N}\left(337.5-22.5^{\circ}\right), \mathrm{NE}\left(22.5-67.5^{\circ}\right), \mathrm{E}\left(67.5-112.5^{\circ}\right)$ SE (112.5-157.5 ), S (157.5-202.5 ), SW (202.5$\left.247.5^{\circ}\right), \mathrm{W}\left(247.5-292.5^{\circ}\right)$ and $\mathrm{NW}\left(292.5-337.5^{\circ}\right)$. The minimum floor altitude $\left(\mathrm{Alt}_{\min }\right)$, maximum headwall altitude (Alt ${ }_{\text {max }}$ ) and mean altitude ( Alt $_{\text {mean }}$ ) of each cirque were automatically derived from the DEM. Finally, bedrock lithology (based on Olivero and Martinioni, 2001, and Olivero and Malumián, 2008) and main structures (after Menichetti et al., 2008; Esteban et al., 2014; Torres-Carbonell et al., 2014, and Bran et al., 2018) were recorded in order to analyse their effect on cirque size and morphology (Fig. 2).

Morphometric parameters were analysed in terms of minimum, average and maximum values,

TABLE 1. DEFINITION OF MORPHOMETRIC ATTRIBUTES OF CIRQUES DIRECTLY MEASURED, AND DERIVATIVES THEREOF (FIG. 4 PORTRAYS SOME DEFINITIONS).

\begin{tabular}{|c|c|}
\hline Morphometric parameter & Definition \\
\hline Length (L) & $\begin{array}{l}\text { Length of median axis, measured along a straight line connecting the midpoint of the cirque } \\
\text { threshold (cirque focus) with the headwall, dividing the cirque plan area into two equal halves } \\
\text { (sensu Evans and Cox, 1995). }\end{array}$ \\
\hline Width (W) & Distance measured along the longest line perpendicular to median axis (sensu Evans and Cox, 1995). \\
\hline Height range $(\mathrm{H})$ & $\begin{array}{l}\text { Difference between minimum altitude of cirque floor }\left(\mathrm{Alt}_{\min }\right) \text { and maximum altitude of cirque } \\
\text { headwall }\left(\mathrm{Alt}_{\max }\right)(\operatorname{sensu} \text { Aniya and Welch, 1981). }\end{array}$ \\
\hline Area (A) & Planar surface of the cirque. Automatically calculated in a GIS. \\
\hline Size & $\sqrt[3]{ } \sqrt{L W H}$ (sensu Evans, 2006a). \\
\hline Mean slope gradient $\left(\mathrm{S}_{\text {mean }}\right)$ & $\begin{array}{l}\text { Mean inclination of the cirque real surface (3D) in degrees. Automatically obtained in a GIS, } \\
\text { based on a slope map generated from a DEM. }\end{array}$ \\
\hline $\mathrm{L} / \mathrm{W}$ ratio & Describes planimetric shape of the cirque, expressing cirque elongation. \\
\hline $\mathrm{L} / \mathrm{H}$ ratio & $\begin{array}{l}\text { Is a measure of cirque incision; lower values indicate larger incision, and consequently higher } \\
\text { overall cirque gradient (Hughes et al., 2007). }\end{array}$ \\
\hline $\mathrm{W} / \mathrm{H}$ ratio & Similar to the $\mathrm{L} / \mathrm{H}$ ratio, this is a measure of cirque incision (Hughes et al., 2007). \\
\hline Circularity index (Circ.) & $\begin{array}{l}\text { Obtained by dividing the perimeter of the cirque by the circumference of a circle with the same } \\
\text { area as the cirque in plan (compactness index of Gravelius, 1914). It describes cirque planform } \\
\text { (values of } 1 \text { means perfect circularity). }\end{array}$ \\
\hline
\end{tabular}


mean, median, standard deviation and percentiles $10 \%$ and $90 \%$. The degree of association between variables was established by multivariate correlation procedures, with the calculation of Pearson's product moment correlation coefficient (r).

\section{Results}

Figure 1B shows 253 first-order cirques and 99 inner cirques identified and mapped in southwestern Fuegian Andes for detailed study. From the total of first-order cirques, $20.2 \%$ are located in valley-head settings and $17.8 \%$ correspond to compound-type cirques, which are usually valley-side cirques (68.9\%). Cirques generally exhibit a clear morphological constitution (i.e., headwall, floor and threshold well defined), and are almost unaltered by post-glacial processes, like fluvial incision and mass movements (Fig. 5).

\subsection{Cirque dimensions and morphology}

The total cirque set covers the $19.5 \%$ of the planar surface encompassed by the mountainous segment considered (intermountain valleys excluded). For $80 \%$ of first-order cirques, length (L) ranges from $380 \mathrm{~m}$ to $1,410 \mathrm{~m}$ (mean $\mathrm{L}=812 \mathrm{~m}$ ), width $(\mathrm{W})$ ranges from $360 \mathrm{~m}$ to $1,430 \mathrm{~m}(809 \mathrm{~m})$ height range $(\mathrm{H})$ varies between $167 \mathrm{~m}$ to $514 \mathrm{~m}(332 \mathrm{~m})$ and area (A) falls in the interval between $0.11 \mathrm{~km}^{2}$ and $1.65 \mathrm{~km}^{2}$
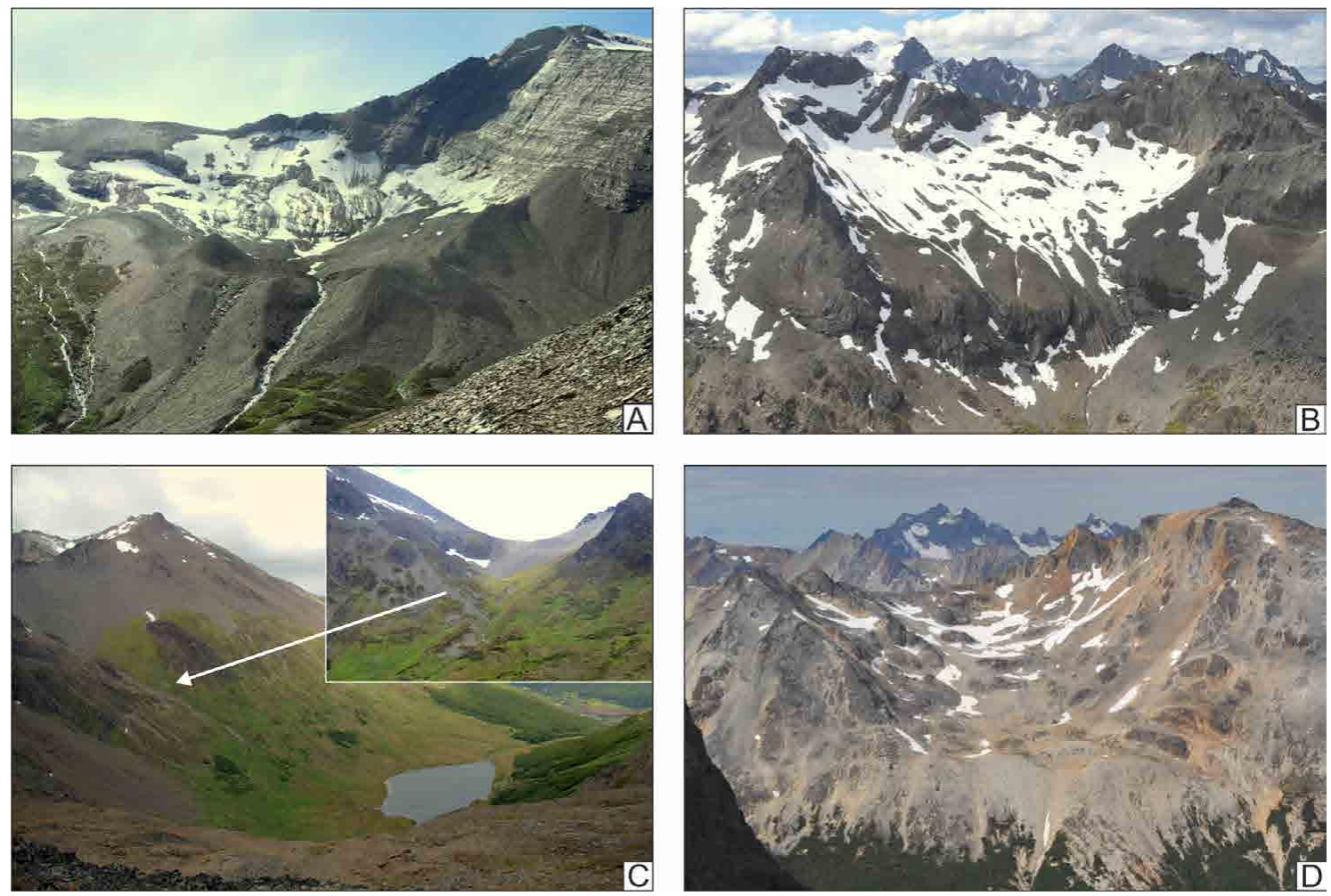

FIG. 5. Photographs of cirques of diverse stages of development, relative position in valleys and bedrock lithology. A. Small valleyhead cirque at the end of Cañadón de la Oveja valley, in the Martial Mountains, closed in the threshold by prominent moraines of the Little Ice Age (Yahgan Formation). B. Steep-floored valley-side cirque from the Martial Mountains, carved on strongly folded metasedimentary units from the Jurassic-Cretaceous (Yahgan Formation). C. A well defined valley-side cirque from the Vinciguerra Range, containing an inner cirque that is visible in the left side of the cirque (shown in frontal view in the inset image) (Yahgan Formation). Laguna Encantada tarn occupies the bottom of the basin. D. A wide valley-side cirque in the Vinciguerra Range, formed on intensely altered volcanic and sedimentary jurassic rocks (Lemaire Formation), with an irregular floor but a clearly distinguishable threshold. Rock bedding perpendicular to former ice flow likely caused variations in bedrock erodibility (i.e., erosion enhanced along-strike), promoting cirque broadening over lengthening. See figure 1B for cirque locations. 
$\left(0.66 \mathrm{~km}^{2}\right)$ (Table 2$)$. Two cirques with significantly higher dimensions than the average were identified, with mean A of $6.71 \mathrm{~km}^{2}$, mean L of $2,300 \mathrm{~m}$, mean $\mathrm{W}$ of $3,700 \mathrm{~m}$ and mean $\mathrm{H}$ of $712 \mathrm{~m}$. These cirques were not considered in the statistical analysis of data because of their unrepresentativeness, therefore all tables and correlations are based on the remaining 251 first-order cirques to which is alluded to in this work. Cirques exhibiting larger planar dimensions are concentrated on the eastern portion of the studied range (E half of Sorondo Range), although the two more areally developed cirques in the set are located towards the W, in the Vinciguerra Range. This range and the Martial Mountains contain the majority of cirques with lower areal extent.

As cirques expand, $\mathrm{L}$ and $\mathrm{W}$ exhibit a higher rise than $\mathrm{H}$ (Fig. 6A); nevertheless, vertical growth is more concomitant with $\mathrm{L}$ than with $\mathrm{W}$. This allometric-type development is also confirmed by the greater degree of correlation of $\mathrm{L}$ and $\mathrm{A}$ with Size and A parameters, compared to the one presented by $\mathrm{H}$ in relation to them: L-Size $(\mathrm{r}=0.92)$ and L-A $(\mathrm{r}=0.91)$; W-Size $(\mathrm{r}=0.92)$ and $\mathrm{W}-\mathrm{A}(\mathrm{r}=0.87)$; H-Size $(\mathrm{r}=0.86)$ and $\mathrm{H}-\mathrm{A}$ $(r=0.67)$ (Table 3$)$. More vertically developed cirques are located with a slight predominance towards the $\mathrm{W}$, in Martial Mountains and Vinciguerra Range, where altitudes and gradients are higher (Fig. 7A).

The L/W shape ratio has a mean value of 1.08 , which remains relatively constant during cirque development: dividing the total cirque population according to size values into four equal intervals (of $410 \mathrm{~m}$ ), mean L/W ratios for each of them, from smaller to bigger size interval, are $1.10(49.8 \%$ of cirque set), $1.05(39,4 \%), 1.06(9.9 \%)$ and 1.03 $(0.8 \%)$, respectively. Circularity, with a mean value of 1.10 , shows the same trend as L/W (mean values of $1.09,1.11,1.10$ and 1.08 for the same increasing size intervals). For $80 \%$ of the cirques, the $\mathrm{L} / \mathrm{W}$ index varies in the range of 0.63-1.57 (Table 2; Fig. 8), and circularity is included in the interval of 1.05 1.17 (Table 2). Cirques with higher L/W values are dominant on the central and western sectors of the study area (Martial Mountains, Vinciguerra Range and western extreme of Sorondo Range), while the lower values are uniformly distributed, although they abound in the central-eastern portion of Sorondo Range (Fig. 7B). The correlation between L, W, and $\mathrm{A}$ is high: $\mathrm{r}=0.77$ between $\mathrm{L}$ and $\mathrm{W} ; \mathrm{r}=0.90$ between $\mathrm{L}$ and $\mathrm{A}$, and $\mathrm{r}=0.87$ between $\mathrm{A}$ and $\mathrm{W}$ (Table 3); this indicates that headwall retreat was generally produced in conjunction with cirque widening (Federici and Spagnolo, 2004; Barr and Spagnolo, 2013). Most of the cirques (80\%) have an $\mathrm{L} / \mathrm{H}$ ratio between 1.56 and 3.51 (mean $\mathrm{L} / \mathrm{H}=2.46$ ) and a W/H ratio from 1.41 to 3.64 (2.48) (Table 2; Fig. 8). Following the same procedure as for $\mathrm{L} / \mathrm{W}$ and circularity versus size, those two parameters show a rise with the increase of cirque size: 2.25 , 2.52, 3.22 and 3.61 for $\mathrm{L} / \mathrm{H}$, and $2.27,2.58,3.09$ and 3.49 for $\mathrm{W} / \mathrm{H}$, correspondingly. Cirques with higher gradients (reduced $\mathrm{L} / \mathrm{H}$ ) are situated preferably in the centre-west sector of the mountain chain, coincidently with smaller cirques and higher altitudes (Fig. 7C).

TABLE 2. STATISTICS OF ANALYSED MORPHOMETRIC VARIABLES FOR 251 FIRST-ORDER CIRQUES IN THE FUEGIAN ANDES.

\begin{tabular}{lcrrrrrrrrrrrr}
\hline & $\mathbf{L}$ & $\mathbf{W}$ & $\mathbf{H}$ & $\mathbf{A}$ & $\mathbf{A l t}_{\min }$ & $\mathbf{A l t}_{\max }$ & $\mathbf{A l t}_{\text {mean }}$ & $\mathbf{L} / \mathbf{H}$ & $\mathbf{W} / \mathbf{H}$ & $\mathbf{L} / \mathbf{W}$ & Size & $\mathbf{S}_{\text {mean }}$ & Circ. \\
\hline Mean & 812 & 809 & 332 & 0.66 & 716 & 1,048 & 873 & 2.46 & 2.48 & 1.08 & 590 & 24 & 1.10 \\
Standard dev. & 437 & 433 & 131 & 0.72 & 145 & 132 & 122 & 0.84 & 0.92 & 0.39 & 262 & 5 & 0.05 \\
Minimum & 140 & 160 & 80 & 0.02 & 309 & 714 & 550 & 1.02 & 0.52 & 0.45 & 121 & 14 & 1.03 \\
Maximum & 2,530 & 2,580 & 836 & 4.47 & 1,092 & 1,356 & 1,159 & 6.39 & 5.58 & 3.12 & 1,761 & 41 & 1.39 \\
Median & 690 & 700 & 327 & 0.4 & 716 & 1,047 & 872 & 2.33 & 2.37 & 1.01 & 535 & 24 & 1.09 \\
Percentile 10 & 380 & 360 & 167 & 0.11 & 538 & 887 & 702 & 1.56 & 1.41 & 0.63 & 286 & 18 & 1.05 \\
Percentile 90 & 1,410 & 1,430 & 514 & 1.65 & 905 & 1,213 & 1,036 & 3.51 & 3.64 & 1.57 & 963 & 31 & 1.17 \\
\hline
\end{tabular}

$\mathbf{A l t}_{\min }:$ minimum floor altitude, $\mathbf{A l t}_{\text {man }}$ : cirque mean altitude, $\mathbf{A l t}_{\max }$ : maximum headwall altitude (all in $\mathrm{m}$ a.s.1); See figure 1B for geographical settings. Remaining abbreviations as in table 1 . 
A

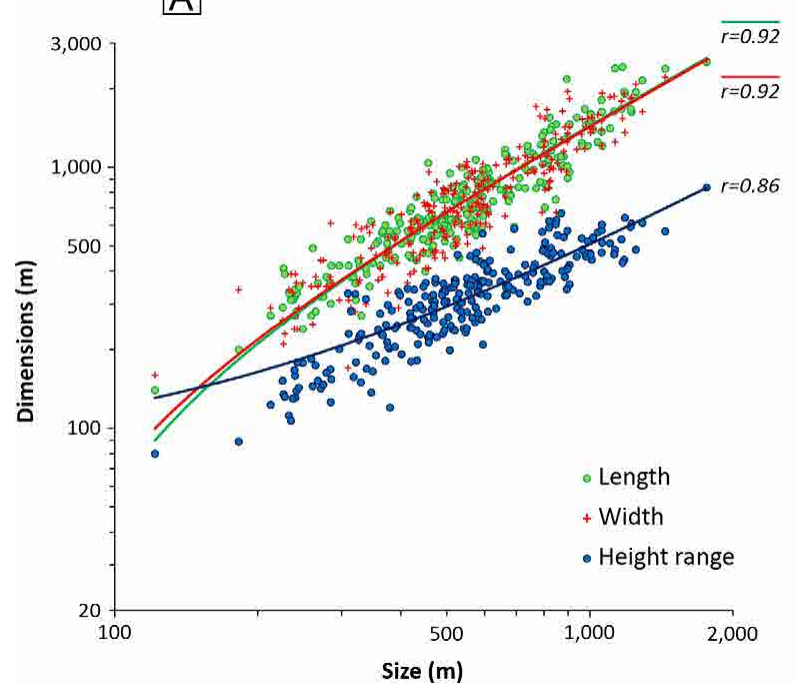

B

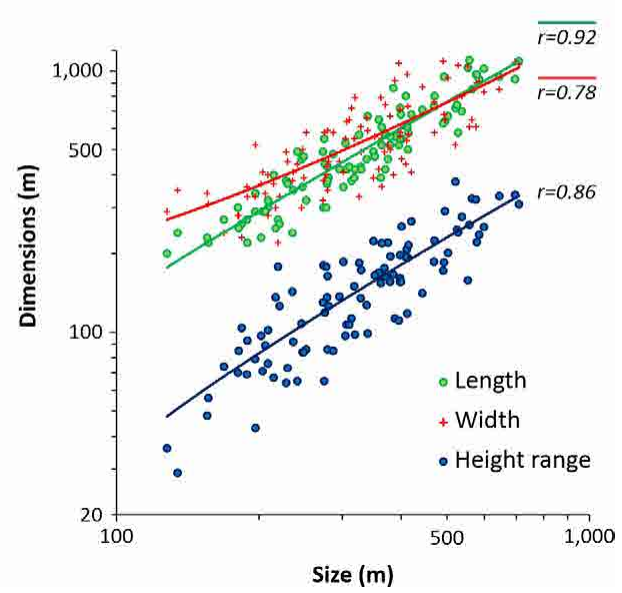

FIG. 6. Correlation diagrams between dimensions of (A) first-order and (B) inner cirques, with length (L), width (W) and height range (H) plotted against size $\left({ }^{3} \sqrt{L A H}\right)$. Allometric properties of cirques are revealed by the reduced gradient of the regression line for height range. Pearson coefficients (r) for individual correlations are included.

TABLE 3. CORRELATION MATRIX AMONG THE ANALYSED ATTRIBUTES OF 251 FIRST-ORDER CIRQUES IN THE FUEGIAN ANDES.

\begin{tabular}{lccccccccccccc}
\hline & $\mathbf{L}$ & $\mathbf{W}$ & $\mathbf{H}$ & $\mathbf{A}$ & $\mathbf{A l t}_{\text {min }}$ & $\mathbf{A l t}_{\text {max }}$ & $\mathbf{A l t}_{\text {mean }}$ & $\mathbf{L / H}$ & $\mathbf{W} / \mathbf{H}$ & $\mathbf{L} / \mathbf{W}$ & Size & $\mathbf{S}_{\text {mean }}$ & Circ. \\
\hline $\mathrm{L}$ & 1 & 0.77 & 0.72 & 0.90 & -0.48 & 0.18 & -0.25 & 0.61 & 0.23 & 0.24 & 0.92 & -0.31 & 0.18 \\
$\mathrm{~W}$ & - & 1 & 0.68 & 0.87 & -0.48 & 0.15 & -0.26 & 0.32 & 0.59 & -0.34 & 0.92 & -0.27 & 0.22 \\
$\mathrm{H}$ & - & - & 1 & 0.67 & -0.54 & 0.39 & -0.18 & -0.05 & -0.12 & 0.06 & 0.86 & 0.25 & 0.15 \\
$\mathrm{~A}$ & - & - & - & 1 & -0.46 & 0.16 & -0.24 & 0.47 & 0.38 & -0.01 & 0.91 & -0.26 & 0.15 \\
$\mathrm{Alt}_{\min }$ & - & - & - & - & 1 & 0.56 & 0.91 & -0.06 & -0.06 & 0.04 & -0.55 & 0.01 & -0.02 \\
$\mathrm{Alt}_{\max }$ & - & - & - & - & - & 1 & 0.82 & -0.12 & -0.18 & 0.11 & 0.24 & 0.26 & 0.12 \\
$\mathrm{Alt}_{\text {mean }}$ & - & - & - & - & - & - & 1 & -0.12 & -0.14 & 0.08 & -0.26 & 0.17 & 0.01 \\
$\mathrm{~L} / \mathrm{H}$ & - & - & - & - & - & - & - & 1 & 0.5 & 0.32 & 0.36 & -0.75 & 0.11 \\
$\mathrm{~W} / \mathrm{H}$ & - & - & - & - & - & - & - & - & 1 & -0.57 & 0.3 & -0.65 & 0.18 \\
$\mathrm{~L} / \mathrm{W}$ & - & - & - & - & - & - & - & - & - & 1 & -0.04 & -0.03 & 0.09 \\
$\mathrm{Size}$ & - & - & - & - & - & - & - & - & - & - & 1 & -0.17 & 0.18 \\
$\mathrm{~S}_{\text {mean }}$ & - & - & - & - & - & - & - & - & - & - & - & 1 & -0.19 \\
Circ. & - & - & - & - & - & - & - & - & - & - & - & - & 1 \\
\hline
\end{tabular}

Abbreviations as in table 1.

Valley-head cirques are equivalent in size and morphology to valley-side cirques. Usually, the largest cirques within the study area are of the compound type and occur at the headwaters of valleys. Inner cirques are smaller in vertical and horizontal dimensions than first-order cirques: $80 \%$ 

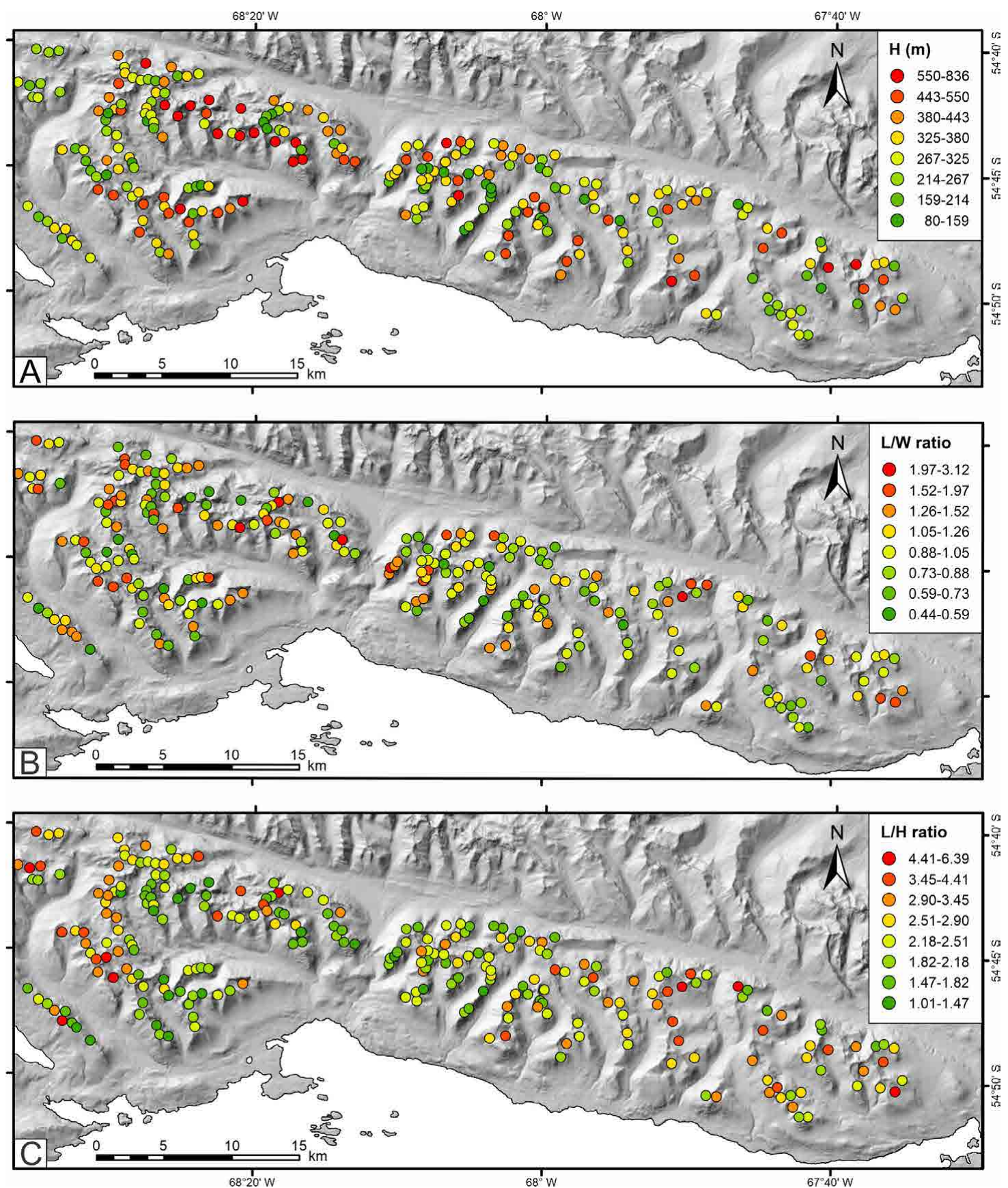

FIG. 7. Spatial distribution of first-order cirques according to A. Height range $(\mathrm{H})$. B. Lengthwise elongation (L/W index). C. Incision ( $\mathrm{L} / \mathrm{H}$ index).

of them have $\mathrm{L}$ between $260 \mathrm{~m}$ and $930 \mathrm{~m}$ (mean $\mathrm{L}=518 \mathrm{~m})$, $\mathrm{W}$ between $310 \mathrm{~m}$ and $910 \mathrm{~m}(555 \mathrm{~m})$, $\mathrm{H}$ between $69 \mathrm{~m}$ and $258 \mathrm{~m}(155 \mathrm{~m})$ and A varies from $0.07 \mathrm{~km}^{2}$ to $0.56 \mathrm{~km}^{2}\left(=0.26 \mathrm{~km}^{2}\right)$ (Table 4$)$.
As observed in first-order cirques, height range in inner cirques is outpaced by lengthening and widening as size increases (Fig. 6B). Inner cirques have a circularity (mean $=1.09)$ and a $\mathrm{L} / \mathrm{W}$ ratio 


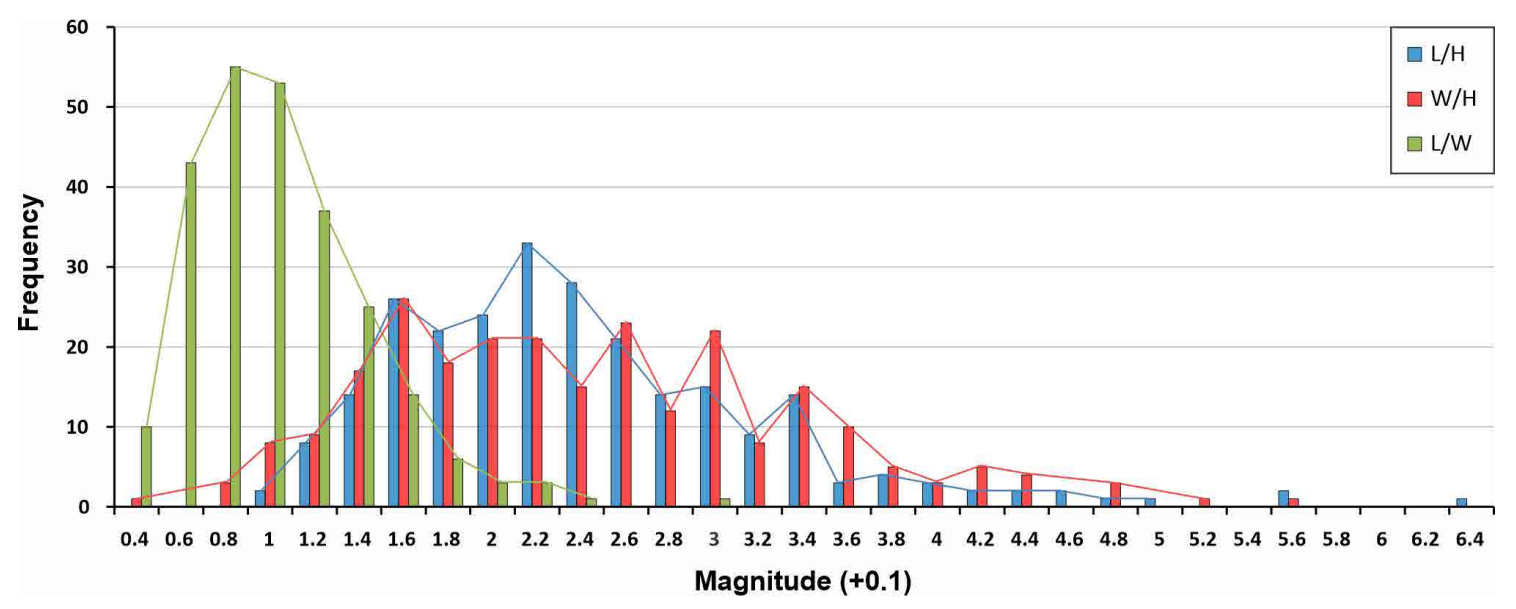

FIG. 8. First-order cirques frequency distribution of $\mathrm{L} / \mathrm{H}, \mathrm{W} / \mathrm{H}$ and $\mathrm{L} / \mathrm{W}$ shape indexes.

TABLE 4. STATISTICS OF ANALYSED MORPHOMETRIC VARIABLES FOR 99 INNER CIRQUES IN THE FUEGIAN ANDES.

\begin{tabular}{lcrrrrrrrrrrrr}
\hline & $\mathbf{L}$ & $\mathbf{W}$ & \multicolumn{1}{c}{$\mathbf{H}$} & $\mathbf{A}$ & $\mathbf{A l t}_{\min }$ & $\mathbf{A l t}_{\max }$ & $\mathbf{A l t}_{\text {mean }}$ & $\mathbf{L} / \mathbf{H}$ & $\mathbf{W} / \mathbf{H}$ & $\mathbf{L} / \mathbf{W}$ & Size & $\mathbf{S}_{\text {mean }}$ & Circ. \\
\hline Mean & 518 & 555 & 155 & 0.26 & 860 & 1,015 & 769 & 3.72 & 4.26 & 0.97 & 346 & 25 & 1.09 \\
Standard dev. & 225 & 221 & 76 & 0.21 & 109 & 112 & 221 & 1.45 & 2.21 & 0.33 & 132 & 7 & 0.05 \\
Minimum & 200 & 220 & 29 & 0.05 & 578 & 696 & 297 & 1.52 & 1.24 & 0.49 & 128 & 10 & 1.02 \\
Maximum & 1,100 & 1,090 & 377 & 0.96 & 1,080 & 1,248 & 1,144 & 8.46 & 12.09 & 2.15 & 709 & 44 & 1.31 \\
Median & 470 & 520 & 150 & 0.21 & 863 & 1,012 & 798 & 3.53 & 3.67 & 0.88 & 328 & 25 & 1.08 \\
Percentile 10 & 260 & 310 & 69 & 0.07 & 707 & 880 & 420 & 2.17 & 2.11 & 0.62 & 189 & 14 & 1.04 \\
Percentile 90 & 930 & 910 & 258 & 0.56 & 1,004 & 1,164 & 1,038 & 5.60 & 7.08 & 1.53 & 553 & 34 & 1.16 \\
\hline
\end{tabular}

Abbreviations as in table 1.

(mean $=0.97)$ similar to first-order cirques, but their mean values of $\mathrm{L} / \mathrm{H}(3.72)$ and $\mathrm{W} / \mathrm{H}(4.26)$ are modestly higher (Table 4).

As expectable, inner cirques tend to grow within the largest first-order cirques, mainly the more developed in height range. In fact, compound cirques (commonly placed in headwater settings: $67,4 \%$ of cases), account for the largest sizes and areas among the studied cirques. For inner cirques, circularity and $\mathrm{L} / \mathrm{W}$ ratio rises weakly with increasing size. For $80 \%$ of inner cirques, $\mathrm{L} / \mathrm{H}$ and $\mathrm{W} / \mathrm{H}$ values are between 2.17 and 5.60 (mean value $=3.72$ ), and from 2.11 to 7.08 (mean value $=4.26$ ), respectively (Table 4 ); both decline moderately as their dimensions enlarge. The remaining characteristics expose similar trends and correlations to those observed for first-order cirques (Table 5), and no proportionality in size or shape parameters between them is noticed.

\subsection{Cirque altitude}

Cirque floor altitudes $\left(\mathrm{Alt}_{\min }\right)$ in the studied ranges are distributed between 309 and $1,092 \mathrm{~m}$ a.s.1., and $80 \%$ of them cover an interval between 538 and $905 \mathrm{~m}$ a.s.l. (mean: $716 \mathrm{~m}$ a.s.l.; standard deviation: $145 \mathrm{~m}$ a.s.1.) (Table 2). Nevertheless, cirque altitude declines from $\mathrm{W}$ to $\mathrm{E}$, in concordance with the reduction of range elevation (Figs. 3 and 9). In the Martial Mountains and the Vinciguerra Range (127 cirques), which constitute the southwest portion of the Argentine Fuegian Andes, the altitude of $80 \%$ of cirque floors is concentrated between 613 and $953 \mathrm{~m}$ a.s.l. (mean: $788 \mathrm{~m}$ a.s.l.; standard deviation: $131 \mathrm{~m}$ a.s.1.), whereas in the eastern portion of Sorondo Range (47 cirques), $80 \%$ of the cirques have an $\mathrm{Alt}_{\text {min }}$ between 440 and $743 \mathrm{~m}$ a.s.1. (mean: $596 \mathrm{~m}$ a.s.l.; standard deviation: $114 \mathrm{~m}$ a.s.l.) 
TABLE 5. CORRELATION MATRIX AMONG THE ANALYSED ATTRIBUTES OF INNER CIRQUES IN THE FUEGIAN ANDES.

\begin{tabular}{lccccccccccccc}
\hline & $\mathbf{L}$ & $\mathbf{W}$ & $\mathbf{H}$ & $\mathbf{A}$ & $\mathbf{A l t}_{\min }$ & $\mathbf{A l t}_{\max }$ & $\mathbf{A l t}_{\text {mean }}$ & $\mathbf{L} / \mathbf{H}$ & $\mathbf{W} / \mathbf{H}$ & $\mathbf{L} / \mathbf{W}$ & Size & $\mathbf{S}_{\text {mean }}$ & Circ. \\
\hline $\mathrm{L}$ & 1 & 0.64 & 0.72 & 0.86 & -0.45 & 0.05 & 0.18 & 0.10 & -0.23 & 0.51 & 0.92 & 0.20 & 0.37 \\
$\mathrm{~W}$ & - & 1 & 0.43 & 0.86 & -0.30 & 0.00 & 0.08 & 0.10 & 0.26 & -0.28 & 0.78 & 0.05 & 0.32 \\
$\mathrm{H}$ & - & - & 1 & 0.63 & -0.32 & 0.37 & 0.26 & -0.52 & -0.63 & 0.41 & 0.86 & 0.23 & 0.22 \\
$\mathrm{~A}$ & - & - & - & 1 & -0.43 & 0.01 & 0.09 & 0.07 & -0.01 & 0.10 & 0.91 & 0.10 & 0.31 \\
$\mathrm{Alt}_{\text {min }}$ & - & - & - & - & 1 & 0.77 & 0.37 & -0.06 & 0.11 & -0.25 & -0.42 & 0.09 & 0.07 \\
$\mathrm{Alt}_{\max }$ & - & - & - & - & - & 1 & 0.53 & -0.41 & -0.31 & 0.03 & 0.17 & 0.24 & 0.22 \\
$\mathrm{Alt}_{\text {mean }}$ & - & - & - & - & - & - & 1 & -0.11 & -0.12 & 0.15 & 0.20 & 0.41 & 0.25 \\
$\mathrm{~L} / \mathrm{H}$ & - & - & - & - & - & - & - & 1 & 0.78 & -0.01 & -0.17 & -0.15 & 0.08 \\
$\mathrm{~W} / \mathrm{H}$ & - & - & - & - & - & - & - & - & 1 & -0.57 & -0.28 & -0.19 & 0.08 \\
$\mathrm{~L} / \mathrm{W}$ & - & - & - & - & - & - & - & - & - & 1 & 0.27 & 0.22 & 0.16 \\
$\mathrm{Size}$ & - & - & - & - & - & - & - & - & - & - & 1 & 0.19 & 0.33 \\
$\mathrm{~S}_{\text {man }}$ & - & - & - & - & - & - & - & - & - & - & - & 1 & 0.12 \\
$\mathrm{Circ}$ & - & - & - & - & - & - & - & - & - & - & - & - & 1 \\
\hline
\end{tabular}

Abbreviations as in table 1.

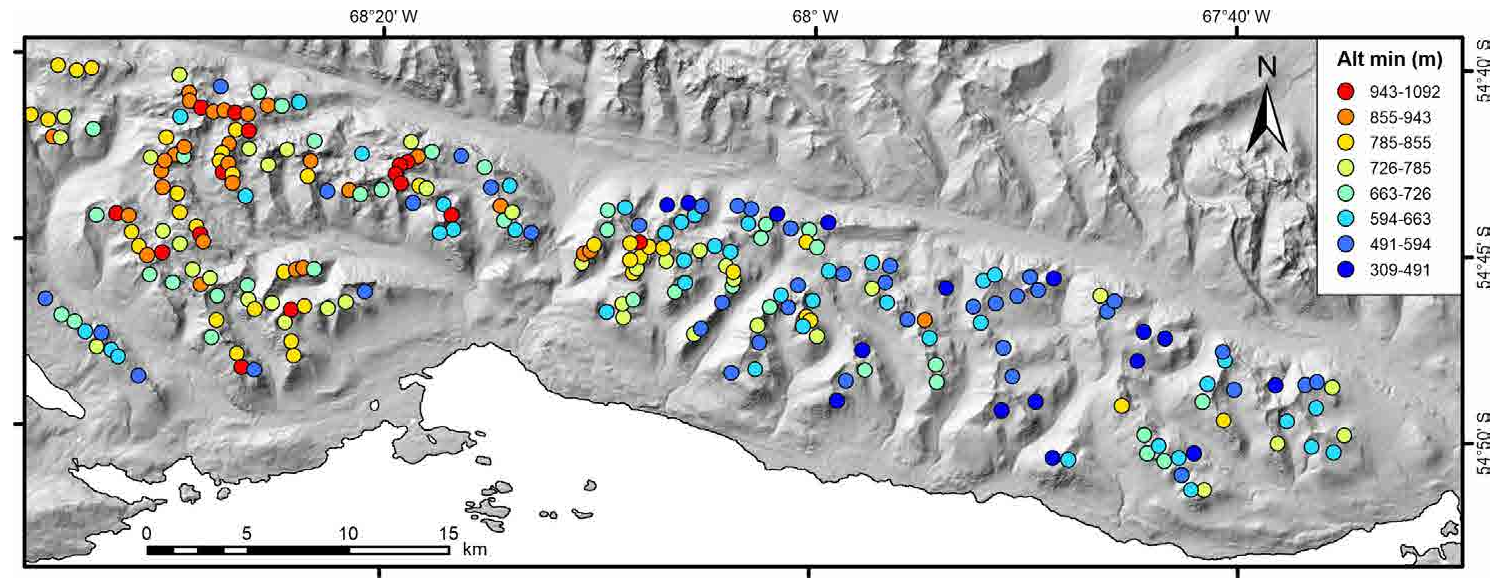

FIG. 9. Geographical distribution of first-order cirques' minimum floor altitude (Alt ${ }_{\min }$ ).

(Table 6). Comprising the entire set of cirques in the studied area, it is observed that $\mathrm{Alt}_{\text {mean }}$ is markedly correlated with $\mathrm{Alt}_{\text {min }}(\mathrm{r}=0.91)$ and $\mathrm{Alt}_{\text {max }}(\mathrm{r}=0.82)$, but the correlation of these altitudinal variables with other metrics is not statistically significant (Table 3). $\mathrm{L}, \mathrm{W}$ and $\mathrm{A}$ attributes show a stronger (negative) correlation with Alt ${ }_{\text {min }}(-0.46<\mathrm{r}<-0.48)$ than with $\mathrm{Alt}_{\text {mean }}$ and $\mathrm{Alt}_{\text {max }}(-0.26<\mathrm{r}<0.18)$. The distribution of cirque floor altitude shows no apparent relationship with azimuth, with highest cirques facing $\mathrm{W}\left(\mathrm{Alt}_{\min }\right.$ : $781 \mathrm{~m}$ a.s.1.; $9.6 \%$ of the studied set), $\mathrm{S}$ ( $\mathrm{Alt}_{\text {min }}$ :
$749 \mathrm{~m}$ a.s.l.; $16.3 \%$ ) and $\mathrm{SW}\left(\mathrm{Alt}_{\min }\right.$ : $743 \mathrm{~m}$ a.s.l.; $10.8 \%$ ), and lowest cirques exposed to the $\mathrm{N}$ (627 $\mathrm{m}$ a.s.1.; 7.6\%), NW (647 $\mathrm{m}$ a.s.1.; 3.6\%) and NE (673 m a.s.1.; 13.6\%) (Table 7).

Cirques situated at lower topographic positions are more likely to contain inner cirques, and these are located at higher altitudes than first-order cirque floors (Tables 2 and 4). For $80 \%$ of inner cirques, $\mathrm{Alt}_{\min }$ ranges from 707 to $1,004 \mathrm{~m}$ a.s.l. (mean= $860 \mathrm{~m}$ a.s.l.; standard deviation=109 $\mathrm{m}$ a.s.l.) (Table 4). Correlations of $\mathrm{Alt}_{\text {mean }}$ with $\mathrm{Alt}_{\text {min }}(\mathrm{r}=0.37)$ and $\mathrm{Alt}_{\text {max }}$ 
TABLE 6. STATISTICS OF ALTITUDINAL PARAMETERS FOR FIRST-ORDER CIRQUES IN THE STUDIED RANGES.

\begin{tabular}{lcrc}
\hline \multicolumn{4}{l}{ Martial Mountains - Vinciguerra Range } \\
\hline $\mathbf{n = 1 2 7}$ & Alt $_{\text {min }}$ & Alt $_{\text {max }}$ & Alt $_{\text {mean }}$ \\
\hline Mean & 788 & 1,132 & 343 \\
Standard dev. & 131 & 106 & 143 \\
Minimum & 526 & 846 & 89 \\
Maximum & 1,092 & 1,356 & 748 \\
Median & 792 & 1,136 & 329 \\
Percentile 10 & 613 & 979 & 169 \\
Percentile 90 & 953 & 1,269 & 571 \\
\hline
\end{tabular}

\begin{tabular}{lcrc}
\hline \multicolumn{2}{l}{ Eastern Sorondo Range } & & \\
\hline $\mathbf{n = 4 7}$ & Alt $_{\text {min }}$ & Alt $_{\text {max }}$ & Alt $_{\text {mean }}$ \\
\hline Mean & 596 & 934 & 338 \\
Standard dev. & 114 & 96 & 133 \\
Minimum & 309 & 714 & 137 \\
Maximum & 802 & 1,146 & 836 \\
Median & 597 & 926 & 324 \\
Percentile 10 & 440 & 796 & 192 \\
Percentile 90 & 743 & 1,054 & 511 \\
\hline
\end{tabular}

$\mathbf{A l t}_{\text {min }}:$ (minimum floor altitude), $\mathbf{A l t}_{\text {mean }}$ : (cirque mean altitude), $\mathbf{A l t}_{\text {max }}$ : (maximum headwall altitude) (all in $\mathrm{m}$ a.s.l). See figure 1B for geographical settings.

TABLE 7. MEAN VALUES OF THE ANALYSED ATTRIBUTES FOR FIRST-ORDER CIRQUES WITH RESPECT TO THE MAIN EIGHT AZIMUTHAL CLASSES.

\begin{tabular}{|c|c|c|c|c|c|c|c|c|}
\hline Azimuth & $\mathbf{N}$ & NE & $\mathbf{E}$ & SE & $\mathbf{S}$ & SW & $\mathbf{W}$ & NW \\
\hline Number of cirques & 19 & 34 & 40 & 57 & 41 & 27 & 24 & 9 \\
\hline Percentage of total & 7.57 & 13.55 & 15.94 & 22.71 & 16.33 & 10.76 & 9.56 & 3.59 \\
\hline $\mathrm{L}(\mathrm{m})$ & 770 & 763 & 808 & 873 & 917 & 696 & 776 & 688 \\
\hline $\mathrm{W}(\mathrm{m})$ & 808 & 822 & 855 & 808 & 856 & 712 & 747 & 821 \\
\hline $\mathrm{H}(\mathrm{m})$ & 358 & 337 & 320 & 333 & 364 & 287 & 316 & 333 \\
\hline $\mathrm{A}\left(\mathrm{km}^{2}\right)$ & 0.55 & 0.69 & 0.65 & 0.76 & 0.83 & 0.44 & 0.51 & 0.56 \\
\hline $\mathrm{Alt}_{\min }$ (m a.s.1.) & 627 & 673 & 710 & 722 & 749 & 743 & 781 & 647 \\
\hline $\mathrm{Alt}_{\max }(\mathrm{m}$ a.s.l. $)$ & 985 & 1,009 & 1,030 & 1,055 & 1,113 & 1,030 & 1,097 & 980 \\
\hline $\mathrm{Alt}_{\text {mean }}$ (m a.s.l.) & 796 & 839 & 863 & 877 & 922 & 879 & 921 & 803 \\
\hline $\mathrm{L} / \mathrm{H}$ & 2.27 & 2.21 & 2.56 & 2.61 & 2.54 & 2.46 & 2.49 & 2.10 \\
\hline $\mathrm{W} / \mathrm{H}$ & 2.37 & 2.42 & 2.73 & 2.43 & 2.35 & 2.69 & 2.40 & 2.45 \\
\hline $\mathrm{L} / \mathrm{W}$ & 1.00 & 1.03 & 1.04 & 1.14 & 1.16 & 0.98 & 1.12 & 0.99 \\
\hline Size (m) & 594 & 582 & 593 & 604 & 646 & 515 & 559 & 561 \\
\hline $\mathrm{S}_{\text {mean }}($ degrees $)$ & 25 & 25 & 23 & 24 & 26 & 23 & 24 & 25 \\
\hline Circularity & 1.10 & 1.09 & 1.11 & 1.10 & 1.09 & 1.10 & 1.09 & 1.12 \\
\hline Land surface \% & 11.9 & 12.9 & 12.2 & 13.2 & 15 & 15.2 & 10.7 & 8.8 \\
\hline
\end{tabular}

Abbreviations as in table 1.

$(\mathrm{r}=0.53)$ are much weaker for inner cirques, and correlations between these variables and the remaining parameters are also low (Table 5). Inner cirques occupying higher positions are exposed to the $\mathrm{N}$ $\left(\mathrm{Alt}_{\min }=919 \mathrm{~m}\right.$ a.s.l.; $11.1 \%$ of the studied set $)$ and $\mathrm{W}$ (884 $\mathrm{m}$ a.s.1.; $8.1 \%$ ), while the lower ones face towards the SE (Alt min $_{1}: 808 \mathrm{~m}$ a.s.1.; 15.2\%), E (839 $\mathrm{m}$ a.s.1.; 19.2\%) and S (841 m a.s.l.; 14.1\%) (Table 8).

\subsection{Cirque azimuth}

When the entire first-order cirque population is considered, it shows a mean aspect of $134^{\circ}(\mathrm{SE})$ (Fig. 10A). The largest number of cirques $(22.7 \%)$ is found in the range of $112.5^{\circ}$ to $157.5^{\circ}$ (SE) (Table 7), with the highest frequency peak in the $120-130^{\circ}$ interval (8.5\%). Other common aspects are $\mathrm{S}(16.3 \%)$ 
TABLE 8. MEAN VALUES OF THE ANALYSED MORPHOMETRIC PARAMETERS FOR INNER CIRQUES WITH RESPECT TO THE MAIN EIGHT AZIMUTHAL CLASSES.

\begin{tabular}{|c|c|c|c|c|c|c|c|c|}
\hline Azimuth & $\mathbf{N}$ & NE & $\mathbf{E}$ & SE & $\mathbf{S}$ & SW & $\mathbf{W}$ & NW \\
\hline Number of cirques & 11 & 13 & 19 & 15 & 14 & 10 & 8 & 9 \\
\hline Percentage of total & 11.1 & 13.1 & 19.2 & 15.2 & 14.1 & 10.1 & 8.1 & 9.1 \\
\hline $\mathrm{L}(\mathrm{m})$ & 397 & 418 & 585 & 633 & 541 & 437 & 554 & 518 \\
\hline $\mathrm{W}(\mathrm{m})$ & 484 & 535 & 556 & 567 & 602 & 598 & 568 & 535 \\
\hline $\mathrm{H}(\mathrm{m})$ & 142 & 117 & 174 & 171 & 154 & 110 & 175 & 186 \\
\hline $\mathrm{A}\left(\mathrm{km}^{2}\right)$ & 0.16 & 0.21 & 0.31 & 0.33 & 0.30 & 0.22 & 0.23 & 0.27 \\
\hline $\mathrm{Alt}_{\min }$ (m a.s.l.) & 919 & 878 & 839 & 808 & 841 & 883 & 884 & 875 \\
\hline $\mathrm{Alt}_{\max }$ (m a.s.1.) & 1,061 & 995 & 1,013 & 979 & 995 & 993 & 1,059 & 1,061 \\
\hline $\mathrm{Alt}_{\text {mean }}(\mathrm{m}$ a.s.1.) & 780 & 647 & 715 & 778 & 731 & 877 & 908 & 778 \\
\hline $\mathrm{L} / \mathrm{H}$ & 3.03 & 3.88 & 3.71 & 3.95 & 4.13 & 4.50 & 3.38 & 2.89 \\
\hline $\mathrm{W} / \mathrm{H}$ & 3.62 & 5.08 & 3.84 & 3.76 & 4.69 & 6.36 & 3.69 & 3.17 \\
\hline $\mathrm{L} / \mathrm{W}$ & 0.90 & 0.83 & 1.06 & 1.14 & 0.98 & 0.75 & 1.03 & 0.95 \\
\hline Size (m) & 295 & 292 & 374 & 388 & 361 & 298 & 371 & 368 \\
\hline $\mathrm{S}_{\text {mean }}$ (degrees) & 23 & 24 & 26 & 24 & 27 & 26 & 27 & 22 \\
\hline Circularity & 1.09 & 1.11 & 1.08 & 1.1 & 1.1 & 1.06 & 1.09 & 1.1 \\
\hline Land surface $\%$ & 11.9 & 12.9 & 12.2 & 13.2 & 15 & 15.2 & 10.7 & 8.8 \\
\hline
\end{tabular}

Abbreviations as in table 1.
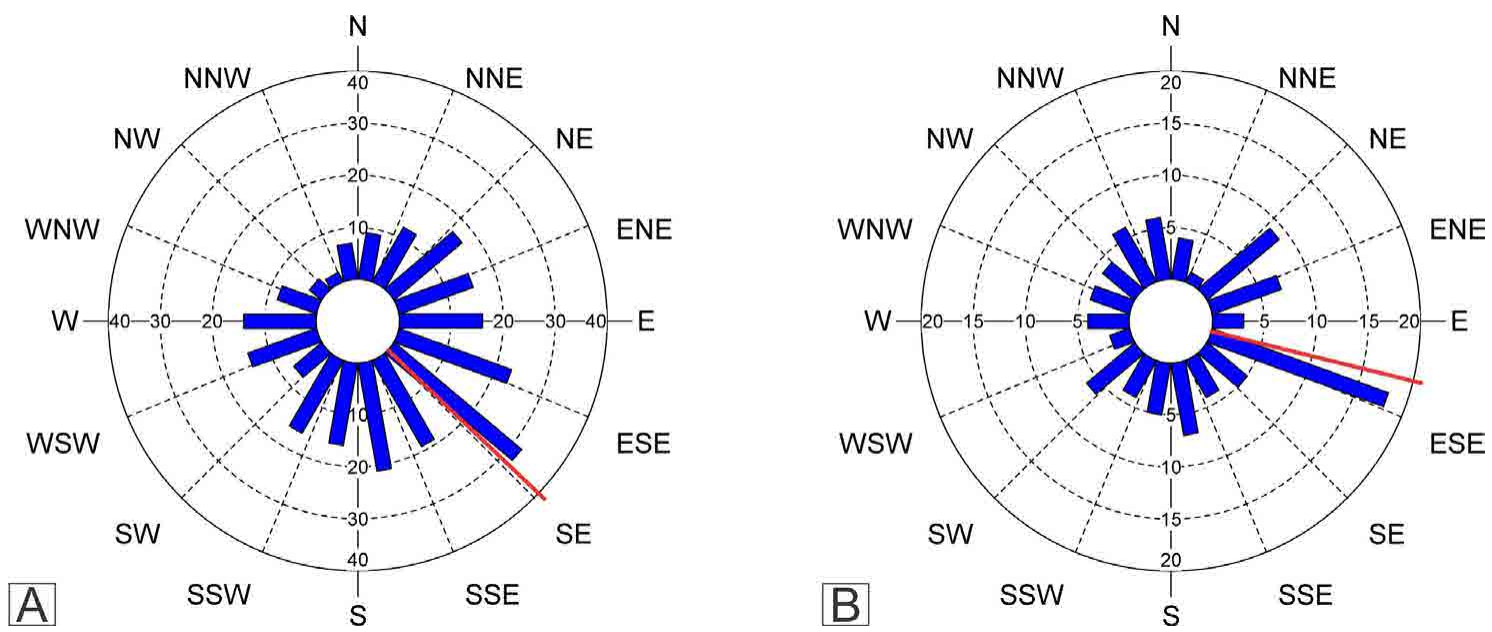

FIG. 10. Distribution of (A) first-order and (B) inner cirques according to their median axis aspect. The red radial line denotes the mean azimuth of cirque population.

and $\mathrm{E}(15.9 \%)$, and only $3.6 \%$ of cirques are NWfacing (Table 7). In general, southward orientations (SW, S, SE; $247.5^{\circ}$ to $112.5^{\circ}$ ) (Fig. 11) include a higher proportion of cirques $(49.8 \%)$ than northward aspects (NW, N, NE; $292.5^{\circ}$ to $\left.67.5^{\circ}\right)(24.7 \%)$. Inner cirques present a sensible scattering in their aspect compared to first-order cirques, with a strong ESE bias (mean aspect of $104^{\circ}$ ) (Fig. 10B; Table 8), and the highest azimuthal peak in the $110-120^{\circ}$ segment $(9 \%)$. Less frequently, inner cirques are disposed to 

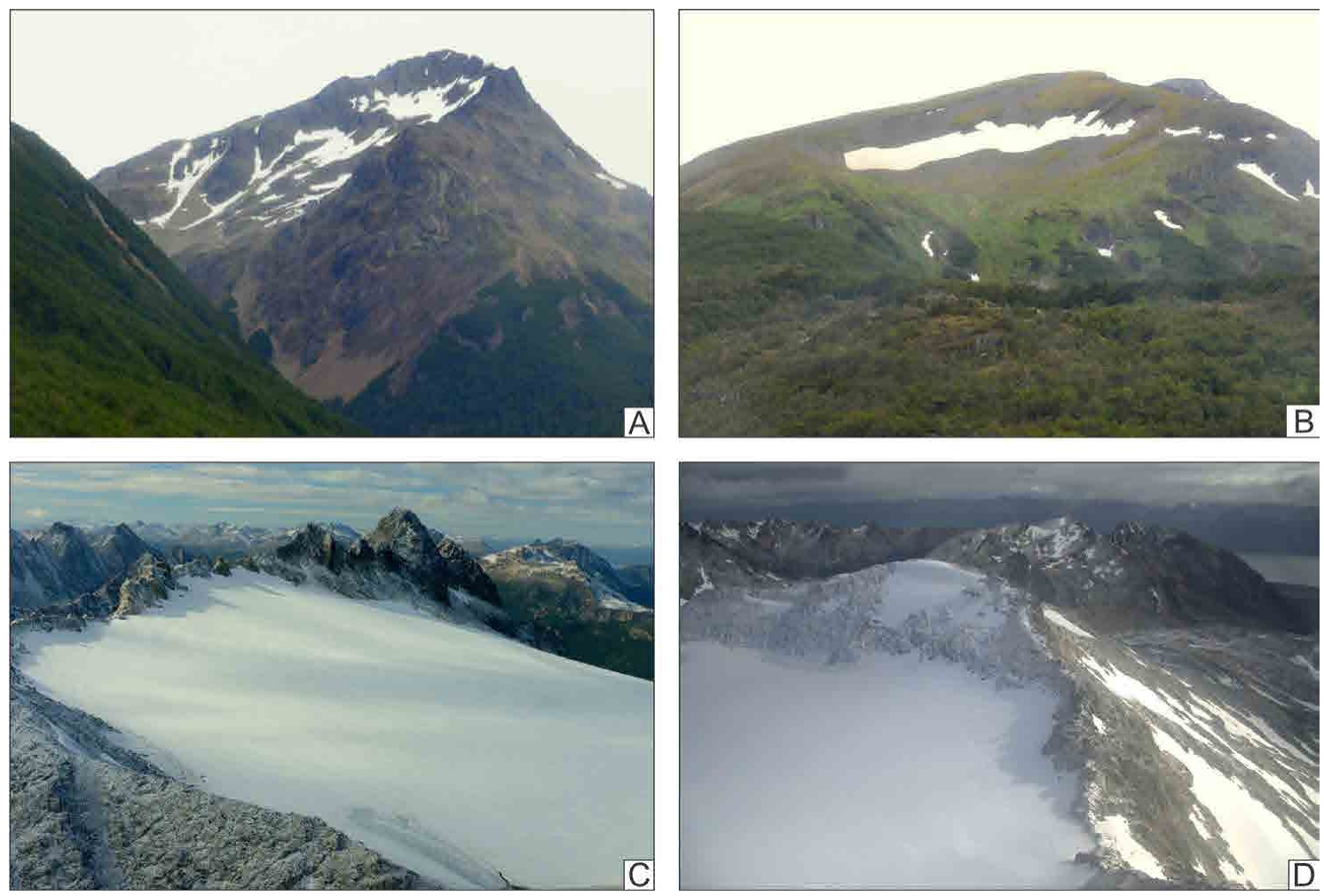

FIG. 11. Glacial cirques exposed to the S-SE-E interval, which represents the most climatically favoured aspect for glacial mass balance. Photographs were taken between January and March, when snow from previous winter was still present in the most sheltered parts of cirques (A and B), or was covering the entire surface of small ice bodies that persist in the highest sectors of some cirques (C and D). (Location of cirques: A. Martial Mountains; B. Vinciguerra Range; C-D. Alvear Range, just in front of Vinciguerra Range).

the SE (15.2\%) and S (14.1\%), and only $8.1 \%$ face $W$. Compared with first-order cirques, there are fewer inner cirques oriented to the three southward sectors (SW, S, SE; 39.4\%), and relatively more of them with northward aspects (NW, N, NE; 33.3\%) (corresponding values for first-order cirques are $50.1 \%$ and $24.9 \%$ ). Whatever their aspect, inner cirques tend to form mostly inside E- to S-facing cirques.

\subsection{Lithology}

Three lithological classes in different surface proportions are distinguished in the area: the rocks of the Lapataia Formation (phyllites and amphibolites) (7\%), those of the Lemaire Formation (schists, breccias and rhyolites) (41\%) and those of the Yahgan Formation (black shales, tuffs and sandstones) (52\%) (Fig. 2). Only nine cirques were counted in the domain of the Lapataia Formation (3.6\% of the total set), on the sides of two valleys, whilst the remaining cirques are equitably distributed on rocks of the Lemaire (44.6\%) and Yahgan (51.8\%) formations.

No significant differences between morphometric and altitudinal properties were observed in cirques developed on both dominant lithological types, although cirques formed on rocks of the Yahgan Formation (Fig. 5A, B and C) have mean size (608) and mean altitudinal parameters (mean $\mathrm{Alt}_{\text {min }}, \mathrm{Alt}_{\text {max }}$, $\mathrm{Alt}_{\text {mean }}=724,1,069$ and $891 \mathrm{~m}$ a.s.1., respectively) slightly higher than those developed on rocks of the Lemaire Formation (Fig. 5D) (mean size $=580$; mean $\mathrm{Alt}_{\text {min }}, \mathrm{Alt}_{\text {max }}, \mathrm{Alt}_{\text {mean }}=713,1,033,859 \mathrm{~m}$ a.s.l., correspondingly). On the rocks of the Yahgan Formation, which constitutes most of the southern regional slope of the study area, $61 \%$ of the cirques face SE, and only $19 \%$ of them face $\mathrm{N}$ sector, whereas on the rocks of the Lemaire Formation, which mostly conforms the northern slopes, cirques 
exposed to the SE sectors (SW, S, SE) reach $50 \%$, and those facing the N intervals (NW, N, NE), $26 \%$. On the other hand, cirques whose aspects certainly follow the dominant terrain alignments are found in comparable proportions on both lithological types, indicating that structure affects them similarly.

The rocks of the Lemaire Formation support a proportion of inner cirques modestly higher (56.7\%) than those on rocks of the Yahgan Formation (43.3\%), possibly because the former includes the 2 oversized cirques mentioned, which possess a higher amount of small cirques inside (12 inner cirques among both) (Figs. 1B and 2). The altitude and azimuth of inner cirques is similar in both lithological types, but it is observed that inner cirques developed on rocks of the Lemaire Formation are somewhat larger (mean values: $\mathrm{L}=553 \mathrm{~m} ; \mathrm{W}=582 \mathrm{~m} ; \mathrm{A}=0.30 \mathrm{~km}^{2} ; \mathrm{H}=170 \mathrm{~m}$ ) than those formed on rocks of the Yahgan Formation (mean values: $\mathrm{L}=482 \mathrm{~m}$; $\mathrm{W}=527 \mathrm{~m}$; $\mathrm{A}=0.22 \mathrm{~km}^{2}$; $\mathrm{H}=139 \mathrm{~m})$.

\section{Discussion}

\subsection{Size and shape}

Cirques in the Fuegian Andes are approximately circular in planform (mean L/W and mean circularity: 1.08 and 1.10, respectively; Table 2), reflecting a common tendency verified in other mountainous regions of the world (cf. Barr and Spagnolo, 2015). No significant correlation is noticed between cirque type, either "simple" or "compound", and circularity and $\mathrm{L} / \mathrm{W}$ indexes, that is, both circular and elongated cirques are prone to include inner cirques. When $\mathrm{L} / \mathrm{H}$ and $\mathrm{W} / \mathrm{H}$ indexes decrease (i.e., gradient rises), cirques tend to be of the simple type and are located in the sides of valleys. On the other hand, valley head locations seem to provide more space for cirque floor expansion, generating lower gradient cirques.

It has been globally observed that cirques tend to grow significantly more in planar dimensions than in depth, evolving in an allometric manner (e.g., Gordon, 1977; Olyphant, 1981; Evans, 2006a; RuizFernández et al., 2009; Ebrahimi and Seif, 2017). This is probably because, as glaciation intensifies, cirques are occupied by cold-based glaciers with low surface gradient (i.e., reduced rotational flow) that overflow their basins and channel into valleys, promoting wall erosion over bedrock incision (phase II of mountain glaciations; e.g., Federici and Spagnolo, 2004; Evans, 2006a; Barr and Spagnolo, 2013). According to this mechanism, it is also expected that headward retreat exceeds widening, so that cirques develop more lengthwise than transversely (Derbyshire and Evans, 1976; Steffanová and Mentlík, 2007; Evans, 2010). However, it must be kept in mind that subglacial denudation is supposed to be greater at the beginning of glaciation and during glacial retreat (phases I and III of mountain glaciations or "cirque-type glaciation"; e.g., Federici and Spagnolo, 2004; Barr and Spagnolo, 2013) than under extended glacial conditions, since in those stages cirque glaciers are usually small and warm-based, with a gradient high enough to produce rotational flow (e.g., Federici and Spagnolo, 2004). Besides, the number of freeze-thaw cycles (Sanders et al., 2012; Delmas et al., 2015) and clast supply to glacier-load (Crest et al., 2017) increases by then, largely enhancing wall erosion.

In the Fuegian Andes, cirque horizontal dimensions indeed display a growth rate greater than that of depth (Fig. 6), but L/W ratio remains virtually constant and close to 1 as cirques enlarge, and has no correlation with size and area parameters (Table 3). As a first approximation, this data would suggest that glaciers stayed a considerable period restricted to cirque confines, sapping the headwall and lateral margins at similar rates, but that phase II of glaciation was important in cirque modelling as well, inhibiting floor deepening to some extent, although not so much as to produce dominant elongated shapes. In support of these observations, attending to L/W classification proposed by Damiani and Pannuzi (1987) for cirques in the Apennines (Italy), it can be assumed that $\sim 51 \%$ of cirques analysed in this work were mostly eroded by cirque-type glaciers (phases I and III: $0.5<\mathrm{L} / \mathrm{W}<1$ ), $\sim 4 \% \%$ were modelled by glaciers descending through valleys (phase II: $\mathrm{L} / \mathrm{W}>1$ ), and only for 7 cirques erosion was dominated by post-glacial processes $(\mathrm{L} / \mathrm{W}<0.5)$. However, a better comprehension of these relationships can be achieved analysing spatial variations in cirque shape and size attributes verified in the studied range: cirques tend to be more lengthwise elongated, areally smaller, deeper and steeper towards its western half (Martial Mountains, Vinciguerra Range and western extreme of Sorondo Range) (Fig. 7). These trends could be indicative of differences in the geometry and behaviour of glaciers that defined cirque (and trough) development along the mountain section, mainly conditioned by distance to Cordillera Darwin, 
where the ice-mantle that formerly covered the Fuegian Andes came from, and by the W-E altitude gradient of the range (Fig. 3). Both factors should have controlled ice residence time, and altitude would also have had a doubtless impact on slope steepness. In fact, in the last maximum glacial expansion, it is likely that many cirques located above $c a$. 500$700 \mathrm{~m}$ a.s.1. in the western part (landscape below that elevation is supposed to have been completely buried by ice; Coronato, 1995) were occupied by thick glaciers that merged to tributary valley glaciers through short ice tongues, whereas most of ice filling cirques in the eastern half of the study area (centraleastern Sorondo Range) would have been directly connected to massive valley glaciers, as suggested by the scarce presence of hanging valleys and high proportion of valley-side cirques found there. After the LGM, extent and thickness of the Beagle palaeoglacier began to decrease gradually from $\mathrm{E}$ to $\mathrm{W}$ (as well as volume of the ice cap that partially covered the mountain chain) (Rabassa et al., 2000). Thereby, it is thought that when glaciers stabilized during the Lateglacial, Beagle palaeoglacier snout had retreated to a maximum position of about $10 \mathrm{~km}$ east of the eastern end of Sorondo Range, in Puerto Harberton area (Heusser, 1989; Rabassa et al., 1990b) (Fig. 1A), and that its thickness had decreased by a minimum of $550 \mathrm{~m}$ in front of Ushuaia, depositing lateral moraines at $300 \mathrm{~m}$ a.s.l. in that location (Pista de Ski and Cerro Quemado Moraines; Rabassa et al., 1990b; Coronato, 1995). By that time, glaciers occupying tributary valleys and cirques in mountains adjacent to Beagle Channel would have had evident individual dynamics, expanding downslope to their maximum Lateglacial positions (Rabassa et al., 2000) and depositing their moraines between 500 and $600 \mathrm{~m}$ a.s.l. (this would imply an ELA approximately 350-450 $\mathrm{m}$ above LGM estimated ELA; Rabassa et al., 1990b). Cirque glaciers in particular, then should have been highly dynamic, eroding their basins not so far above those elevations. This agrees with the fact that $90 \%$ of cirque floors here analysed are placed above $538 \mathrm{~m}$ a.s.l. (the 10-percentile of floor altitude is a suitable estimate of lowest former ELA; Mîndrescu and Evans, 2014) (Table 2), and with distribution of cirque's Alt ${ }_{\min }$ noticed in figures 3 and 9, which show scarce cirques (even less in the W part) with floors below that altitude.

Under this scenario -that possibly has repeated throughout the different Quaternary cold pulses- it would be reasonable to suppose that, after maximum glacial stages, valley glaciers towards the eastern part of the investigated area, topographically lower and farther from the former Cordillera Darwin icefield, disconnected from the Beagle Glacier and acquired independent glaciological behaviour earlier than to the west. This implies that many ice bodies in central-eastern Sorondo Range should have been restricted only to cirque confines by then, actively eroding their depressions. Thereby, glaciations in this mountainous segment would have had marginal characteristics for more extended periods -both at early and late stages of major cold events- in comparison to Martial Mountains and Vinciguerra Range. Likewise, assuming that eastern domains remained uncovered by ice for longer, post-glacial processes are supposed to have been more important in cirque modelling there. This is sustained by prevalence of broader (Fig. 7B) and areally larger (Fig. 1B) cirques in that sector, as sidewall expansion is generally favoured by the emplacement of highly erosive cirque-type glaciers and by the occurrence of periglacial and non-glacial processes (e.g., Federici and Spagnolo, 2004; Steffanová and Mentlík, 2007; Delmas et al., 2015). Inversely, the greater persistence of (lowerosive) ice-sheet conditions in Martial Mountains and Vinciguerra Range would have inhibited growth of larger cirques there. Also, ice bodies occupying cirques in that area would have been connected to tributary valley glaciers (either directly or through glacial tongues) comparatively for longer during cold periods -with the ELA well below cirque floors-, eroding bedrock beyond cirque thresholds and thus enhancing cirque lengthening over widening (e.g., Seif and Ebrahimi, 2014; Ebrahimi and Seif, 2017).

\subsection{Influence of altitude on cirque size and shape}

Although coincidence between rise in range elevation and proximity to former Cordillera Darwin icefield makes it difficult to assess their respective incidence on cirque development, some of the tendencies observed in cirque morphometry along the studied mountain section reveal characteristics that could be attributable to an altitude-related control exclusively. In fact, whereas most of surveyed cirque floors $(80 \%)$ are concentrated in an altitude interval between 538 and $905 \mathrm{~m}$ a.s.l. (Table 2), a gradient in cirque floor mean elevation, consistent with mountain height decrease, is verified from Martial Mountains and 
Vinciguerra Range (788 m a.s.1.) to eastern Sorondo Range (596 m a.s.1.) (Table 6; Figs. 3 and 9). Although the action of small, dynamic cirque-type glaciers -which would have been typical of the eastern partshould favour the excavation of cirque beds besides wall erosion (e.g., Barr and Spagnolo, 2013; Crest et al., 2017), the fact that cirques of greater height range are more abundant towards the west (Fig. 7A) may be partly a consequence of higher topographic levels there, which would have forced many cirque glaciers to develop on more pronounced slopes (i.e., leading to greater distance between minimum and maximum cirque altitudes). This could also have contributed to the slightly greater proportion of lengthwise elongated (and downward steeper) cirques accounted in that sector (Fig. 7B), as cirque glaciers in such relief conditions would have tended more to expand downvalley than to increase in thickness, and hence cirque erosion would have been dominated more by linear than by rotational ice flow. In support of these observations, table 9 actually shows a modest increment in incision and $\mathrm{L} / \mathrm{W}$ index with cirque floor elevation along the studied range. Likewise, the notable reduction noticed in cirque size with cirque altitude (Table 9), also evidenced by prevalence of areally smaller cirques towards the west (Fig. 1B), could also be reflecting the fact that, at great heights, close to ridgetops, accommodation space available for cirque expansion is somewhat limited and winds that may constrain snow accumulation are more intense (Kř́žžek and Mida, 2013). In addition, in higher parts of mountains, glaciers filling cirques are less dynamic (as they are usually well above ELA), and periglacial conditions, necessary for cirque enlargement, persist for less time than glacial ones (Démangeot, 1965; García-Ruiz et al., 2000). Finally, the lesser vertical development of larger cirques is in accordance with the allometric growth hypothesized for the analysed cirques (Fig. 6).

On the other hand, inner cirques, roughly half the dimensions of first-order (Figs. 1B and 6B; Table 4), become frequent from around $700 \mathrm{~m}$ a.s.l. (10-percentile of Alt ${ }_{\text {min }}$ ) (Table 4), and also decrease markedly in size and planar surface with increasing elevation. They were probably eroded by shortlived, small ice masses, due to a rise and temporal

TABLE 9. MEAN VALUES OF MORPHOMETRIC PARAMETERS OF FIRST-ORDER CIRQUES DISTRIBUTED ACCORDING TO FLOOR ALTITUDE INTERVALS.

\begin{tabular}{lcccc}
\hline Altitudinal interval & $\mathbf{3 0 0 - 5 0 0}$ & $\mathbf{5 0 0 - 7 0 0}$ & $\mathbf{7 0 0 - 9 0 0}$ & $\mathbf{9 0 0 - 1 , 1 0 0}$ \\
\hline Number of cirques & 16 & 99 & 110 & 26 \\
Percentage of total & 6.37 & 39.44 & 43.82 & 10.36 \\
L (m) & 1,162 & 994 & 672 & 497 \\
W (m) & 1,179 & 961 & 703 & 456 \\
H (m) & 453 & 384 & 298 & 200 \\
A (km $\left.{ }^{2}\right)$ & 1.26 & 0.92 & 0.45 & 970 \\
Alt ${ }_{\text {min }}$ (m a.s.l.) & 438 & 613 & 789 & 1,170 \\
Alt ${ }_{\text {max }}$ (m a.s.l.) & 890 & 997 & 1,087 & 1,066 \\
Alt ${ }_{\text {mean }}$ (m a.s.l.) & 655 & 795 & 929 & 2.53 \\
L/H & 2.50 & 2.56 & 2.36 & 2.40 \\
W/H & 2.58 & 2.52 & 2.45 & 1.13 \\
L/W & 1.06 & 1.07 & 1.07 & 351 \\
Size (m) & 841 & 702 & 509 & 24 \\
$\mathrm{~S}_{\text {mean }}$ (degrees) & 23 & 24 & 25 & 1.09 \\
Circularity & 1.09 & 1.10 & 1.10 & \\
\hline
\end{tabular}

Abbreviations as in table 1. 
stabilization of the ELA just above (between a few tens of meters and just over $100 \mathrm{~m}$ ) the containercirque floor. In fact, they are situated in an altitudinal interval narrower $(80 \%$ of their floor cover a $297 \mathrm{~m}$ range [standard deviation $=109 \mathrm{~m}$ ]; Table 4 ) than that of first-order cirques (367 m [145 m]; Table 2). This is concordant with a lower variability in the ELA during their formation, possibly at a definite phase of a cold event (preferably at the onset or the end of glaciation; e.g., Ponce and Rabassa, 2012), or throughout several glacial cycles (e.g., Federici and Spagnolo, 2004; Mîndrescu and Evans, 2017), in which the ELA settled just above average (compound) cirque floor altitude for a more or less brief period before rising beyond highest summits. Unlike what is observed in other regions, where inner cirques are more probable to develop in mountain areas well above the ELA (e.g., Mîndrescu et al., 2010; Mîndrescu and Evans, 2014), their distribution in the Fuegian Andes shows just limited relationship with elevation, being frequent throughout the entire mountain segment. A feasible explanation for this is that inner cirque erosion was strongly ruled by structure (specially bedding), which would have determined their occurrence itself and their precise location within compound cirques (see Section 6.3.1.). According to this reasoning, it is noticed that inner cirques eroded in rocks of the Lemaire Formation, characterized by a greater lithological variety and coarser beds (i.e., higher differential erodibility) than rocks of the Yahgan Formation (Olivero and Malumián, 2008; Olivero and Martinioni, 2001), are slightly more abundant (56.7\% of the set, against $43.3 \%$ in the Yahgan Formation), as well as modestly larger, although it must be mentioned that $15 \%$ of them are included in the two oversized cirques of Vinciguerra Range (see Fig. 5 to compare the mentioned features between lithological types). Finally, inner cirques tend to be more elongated as altitude increases, suggesting that the ice bodies that eroded them (progressively smaller towards the summits) had gradually less ability to modify structure-controlled pre-glacial topography, evidencing the key role of this factor in cirque formation.

\subsection{Cirque aspect}

\subsubsection{Controls upon cirque aspect}

In the surveyed section of the Fuegian Andes, the azimuthal distribution of first-order cirques tends to be multimodal, although they exhibit a dominant southeasterly orientation: SE, S and E aspects altogether account for $55 \%$ of the cirque set (Fig. 10A; Table 7). This is consistent with the tendency of many cirques and glaciers in Southern Hemisphere (Evans, 1977, 2006b; Glasser et al., 2008; Barr and Spagnolo, 2015). Southward orientation reflects the fact that development of local mountain glaciation (with cirque formation) is promoted on poleward slopes, where solar radiation incidence is minimal and thus limits snow and ice ablation (Fig. 11). This "hemispheric insolation" effect may also be accentuated by winds drifting snow to leeward slopes during cirque erosion phases (Evans, 1977). The eastward component in the cirque azimuth trend identified in this study (Fig. 10A; Table 7) can be attributed to the combined action of i) the westerly winds, which in the LGM and Lateglacial are thought to have been more intense than present day at this latitude (e.g., Wainer et al., 2005; Unkel et al., 2008; Ponce et al., 2011a), and ii) diurnal thermal variations, since slopes exposed to $\mathrm{E}$ receive most of their direct insolation in the morning, when air temperature is relatively low and fusion is weak ("morningafternoon" effect; Evans, 1977, 2006b). Although it is difficult to establish the isolated impact of these two factors on cirque formation, their incidence in the Fuegian Andes seems apparent, given that most of the studied cirques are exposed towards the SE $(22.7 \%)$, and that E-facing cirque frequency $(15.9 \%)$ is relatively high if compared with $\mathrm{S}$-facing cirques $(16.3 \%)$ (Table 7$)$, the latter evidently not affected by these "eastward-deflection" agents. Both trends -southward and eastward bias- have been usually interpreted as indicative of comparatively cloudless skies (i.e., dry atmospheric conditions) in ablation season of former periods of glaciation (Andrews and Dugdale, 1971; Trenhaile, 1976; Evans, 1977). Accepting that a substantial amount of the glacial erosion that modelled cirques in the studied area would have occurred when glaciers begun to retreat after maximum cold episodes in the region (see Section 6.1.), the hypothesis of prevalent dry climate during their formation is supported by numerous investigations suggesting arid to semiarid conditions in LGM and Lateglacial times in Tierra del Fuego and adjacent Isla de los Estados (e.g., Unkel et al., 2008; Ponce et al., 2011a; Berman et al., 2016). This would be mainly attributed to a further north position of westerlies belt in Patagonia by these periods, 
which is supposed to have reduced precipitations in areas south of those latitudes (e.g., Markgraf, 1993; Heusser, 1994; Moreno et al., 1999; McCulloch et al., 2000; Stuut and Lamy, 2004; Compagnucci, 2011). Southerly directions in cirque aspect were also noticed in the western portion of the surveyed mountain segment (Coronato, 1996; Planas et al., 2002) and in Isla de los Estados; in the latter (79 cirques analysed), $34.2 \%$ of cirques (according to the azimuth intervals used in this study) face SE and S, and only $9.7 \%$ face $\mathrm{N}$ (Ponce and Rabassa, 2012). In Islas Malvinas, situated over $500 \mathrm{~km}$ to the NE of the area under investigation, Clapperton (1971) found that almost all cirques are distributed between NE (41\%) and SE (35\%) orientations, and explains that high frequency of the former might be responding to topography and predominance of $\mathrm{W}$ or SW winds in glacial times, factors that would have overshadowed solar radiation effect to some extent.

Cirque aspect can also be affected to a variable degree by the structural configuration of landscape, principally the main ridgeline course and the direction of valleys (e.g., García-Ruiz et al., 2000; Evans, 2006b; Mîndrescu et al., 2010; Simoni, 2011; Bathrellos et al., 2014; Izaguirre et al., 2018). In the Fuegian Andes, bedrock structure is considered to have exerted a marked control on relief morphology, defining glaciers location and ice discharge patterns during cold events (e.g., Coronato, 1995, 1996; Coronato et al., 2009; Ghiglione, 2017). In particular, the presence of pervasive oblique NW-SE trending lineaments, produced by the strike-slip sinistral crustal deformation associated to the E-W/WNWESE oriented BCFZ (Cunningham, 1994, 1995), would have strongly governed the direction of secondary (tributary) glacial troughs (and fjords, in Chilean territory) all along the Beagle Channel margins (Fig. 2), with glaciers widening and deepening these pre-existing geological structures throughout the successive Quaternary cold periods (e.g., Glasser and Ghiglione, 2009; Bran et al., 2018). Likewise, prevailing W-E to NW-SE strike bedding in both dominant lithologies would have provided preferential sites for glacier (and by extension cirque) development, determining to a variable degree their location, morphology and aspect.

In Isla de los Estados, Ponce et al. (2009) noted that predominant SW-NE orientation of glacial valleys and fjords is similar to direction of main fold axis in eastern and western sectors of the island, and to one of the two major sets of transverse faults there present. In regard to cirques, Ponce and Rabassa (2012) highlight that the two dominant aspects, that is, NW (19.5\%) and SE (17.1\%), are coincident with the other set of faults alluded, although it is probable that valley directions, by promoting the formation of cirques so oriented in their flanks, and solar radiation and westerly winds in the case of SE-facing cirques, had contributed to these high percentages as well. In the western part of the study area, Coronato (1996) found the following orientations in cirques analysed in two large valleys, former glacial tributaries of Beagle palaeoglacier: SE (54.7\%) and SW (16.1\%) in Andorra valley, and SW (44.4\%) and S (18.5\%) in Cañadón del Toro valley (Fig. 1B). This author explained the absence of cirques exposed to the $\mathrm{W}$ quadrant as a consequence of local adverse morphological characteristics in both valleys and of W-E direction of the range, and also argued that the non-existence of cirques with northern aspects could be result of a combination of structural and climatic agents, such as insolation and storm episodes.

In the south flank of Sorondo Range, many secondary troughs show a prevailing SW/SSW orientation -deviated from the eastern bias that would be expected according climate influence on glacier development-, whereas in the north flank of this chain and of Martial Mountains and Vinciguerra Range, valleys are mainly NE/ENE-facing (Fig. 2). This configuration could be consequence of the transcurrent deformation associated to the BCFZ, which besides originating the main W-E/WNWESE strike faults parallel and sub-parallel to the Beagle Channel, as well as the oblique set of NW-SE lineaments already mentioned, would have produced a secondary set of associated faults approximately perpendicular to those trends (Glasser and Ghiglione, 2009). Analogously, SW-NE oriented structures were described in the east part of Fagnano Lake as secondary trends differentiated from the predominant W-E/WNW-ESE pattern, in connection to the MFFZ (Lodolo et al., 2003). Likewise, Coronato et al. (2009) found a northeastward orientation in tributary valleys that flowed from Lucio López Range to Fagnano palaeoglacier in its middle-southeastern part (Fig. 1A). On southern slopes of Martial Mountains and Vinciguerra Range, conversely, glacial troughs are oriented predominantly to the SE/SSE, as it is also observed in their equivalents of adjacent Alvear and Beauvoir ranges, to the north, and Lucio López 
Range, eastwards. On the other hand, it is feasible that strike-slip deformation related to the CarbajalLasifashaj sinistral fault system (Caminos et al., 1981) had ruled the development of some of the ENE-facing troughs on northern slopes of Sorondo and Vinciguerra ranges (a similar phenomenon could have occurred in northern flank of Martial Mountains, in connection with the strike-slip fault that crosses Andorra valley).

This analysis provides additional evidence in support of the important role that structure would have played in the arrangement of glacial valleys in the area; however, it should be kept in mind that northeastward and southeastward valley aspects in north and south flanks of the range, respectively, are also the most climatically favoured, implying that both elements, structure and climate, would have ruled trough orientation jointly. Whatever the relative weight of causes responsible for valley framework configuration described above, it is evident that this acted as a significant preconditioning in cirque aspect, as these occur profusely (79.8\% of the total set) in valley margins. Nevertheless, it is noticed that cirques are not equally distributed among both flanks of the interfluves, but show prevailing eastern aspects: along SW-NE/SSW-NNE trending main ridges, cirques face dominantly to the SE and SSE, and when occupy divides with NW-SE/NNE-SSE directions, they usually have NE and $\mathrm{E}$ aspects (Fig. 1B). These patterns would be indicating some predominance of insolation and westerly winds effects over topography and bedrock structure on cirque development, since E-W/WNW-ESE strike transcurrent faults and W-E to NW-SE strike rock bedding should also have promoted formation of cirques with westerly aspects, which only occur in a limited way. In the area covered by Martial Mountains and Vinciguerra Range (127 cirques), for example, the two ridge direction trends observed (NW-SE/NNE-SSE and SW-NE/SSW-NNE) likely propitiated occurrence of cirques facing $\mathrm{S}(22.4 \%)$ and SE (18.4\%), as well as a comparable concentration of NE-facing cirques $(16.8 \%)$, but N (4\%) and NW $(2.4 \%)$ aspects are scarce (Table 10$)$, suggesting that structural control was important, but overshadowed by climate effect. On the other hand, topographic forcing over solar radiation effect seems to be clear in eastern part of Sorondo Range (47 cirques), which despite having lower elevations -that should restrict cirques to the most climatically favourable aspects, since glacial asymmetry increases with decreasing glacial cover (Evans, 1977; Olyphant, 1977)-, presents equivalent dominant cirque orientations as Martial Mountains and Vinciguerra Range: SE (25.5\%) and NE $(21.3 \%)$, as well as a strikingly low percentage of poleward-facing cirques ( $8.5 \%$ ) (Table 10). This could be explained by comparatively more marginal glacial conditions in that sector, which would have limited to some degree the modification of the preglacial landscape by ice erosion.

TABLE 10. DISTRIBUTION OF FIRST-ORDER CIRQUES ACCORDING TO ASPECT IN THE DIFFERENT STUDIED RANGES.

\begin{tabular}{cc}
\hline \multicolumn{2}{c}{$\begin{array}{c}\text { Martial Mountains- } \\
\text { Vinciguerra Range (n=127) }\end{array}$} \\
\hline Azimuth & Percentage of cirques \\
\hline N & 4 \\
NE & 16.8 \\
E & 12.8 \\
SE & 18.4 \\
S & 22.4 \\
SW & 10.4 \\
W & 12.8 \\
NW & 2.4 \\
\hline
\end{tabular}

Eastern Sorondo Range $(n=47)$

\begin{tabular}{cc}
\hline Azimuth & Percentage of cirques \\
\hline N & 10.6 \\
NE & 21.3 \\
E & 10.6 \\
SE & 25.5 \\
S & 8.5 \\
SW & 8.5 \\
W & 6.4 \\
NW & 8.5 \\
\hline
\end{tabular}


Finally, eastern preference noticed in cirque aspect in the analysed sector could also be accentuated by prevalence of slopes exposed to the S, SE and E ( $40.4 \%$ of the total area; $55 \%$ of cirque population) over those facing $\mathrm{N}, \mathrm{NW}$ and $\mathrm{W}$, the most climatically adverse aspects $(31.4 \% ; 20.72 \%)$ (Table 7$)$.

In summary, evidence supports the notion that a combination of geological structure and climate would have acted as a primary control agent on relief organization in the area, establishing cirque aspect in a first instance as a result of the direction of valleys in which they developed. Nevertheless, it can be hypothesized that cirque azimuth and, in many cases cirque occurrence itself, would have responded to an important degree to climatic forcing (i.e., solar radiation and westerly humid winds) that enhanced eastward and southward tendencies despite topographic preconditioning.

In regards of inner cirques, they also exhibit clear aspect asymmetry in their distribution (Fig. 10B; Table 8), denoting the influence of prevailing winds and solar radiation at the time they were formed. Nevertheless, climatically unfavourable aspects in inner cirques are slightly more abundant in comparison to first-order (see Tables 7, 8), likely reflecting prevalent structural control on their orientation. In fact, Mîndrescu and Evans (2014) indicated that inner cirques occurrence seems to be determined mainly by cirque size and geological structure, since larger cirques (specially in height range) are more prone to intersect structural variations (i.e., more erodible zones) that could lead to growth of small cirques inside them. This is confirmed in the study area, as they tend to occur predominantly inside cirques exposed to $\mathrm{E}$ to $\mathrm{S}$, which account for greatest dimensions, and is supported by the relative profusion of inner cirques oriented according to prevalent bedrock bedding and fault sets described above $(\mathrm{E}=19.2 \%$; $\mathrm{NE}=13.1 \%$; $\mathrm{SW}=10.1 \%$; $\mathrm{NW}=9.1 \%$ ) compared to the expectable climatically-strengthened aspects $(\mathrm{SE}=15.2 \% ; \mathrm{S}=14.1 \%)$ (Table 8$)$.

\subsubsection{Influence of altitude on cirque aspect}

Cirque floor altitude across the Fuegian Andes does not show a clear correspondence with azimuth, as usually observed in cirques (and modern glaciers) around the world (Evans, 2006b). In fact, highest cirques face $\mathrm{W}, \mathrm{S}$ and $\mathrm{SW}$, whereas the lowest are exposed to the N, NW and NE (Table 7). This apparently scattered distribution pattern deviates from the expected tendency for Southern Hemisphere, where regional ELAs decreases on southward slopes (exposed to less solar radiation), promoting glacier formation at relatively lower elevations, and is higher on northward slopes, climatically adverse for glacial balance, resulting in glaciers restricted to higher altitudes (Evans, 2006b). A possible explanation for high $\mathrm{W}$ - and SW-facing cirques in the analysed mountains is that slopes so oriented provide -after north/northwestward slopes- the most restrictive climatic conditions for glacier development, which is supported to some extent by the reduced number of cirques found with these aspects $(9.6 \%$ oriented to the W and $10.8 \%$ to the SW; Table 7). Nevertheless, insolation effect as unique control factor cannot explain elevation of cirques exposed to remaining azimuths. Limited evidence (or absence) of aspectrelated variability in cirque floor altitudes (e.g., Evans, 1999; Evans and Cox, 1995) has been interpreted as indicative of cirque growth under comparatively cloudy atmosphere (Evans, 2006b); however, as proposed in Section 6.3.1., solar radiation in the region would have governed cirque aspect to a relatively important degree.

A more feasible hypothesis to explain the altitudinal distribution of studied cirques arises from considering that, in areas where former glaciation was extensive (i.e., where summits rose high above the regional ELA), as it is assumed to have occurred in the surveyed area (e.g., Rabassa et al., 2000), glaciers would have been able to erode cirques at comparatively low topographic levels, even on climatically non-favourable (or less favourable) hillsides (Barr and Spagnolo, 2015). Likewise, this arrangement might also be responding to some extent to the wide altitude interval in which cirques have formed: $80 \%$ of them are placed between 538 and 905 m a.s.l. (Table 2; Fig. 3). This could be interpreted as a consequence of the fact that -accepting that cirques are typically expanded over numerous glacial cycles of different magnitudes (e.g., Evans, 2013; Barr and Spagnolo, 2015)- on climatically favoured slopes there are additional cirques that are higher, smaller and younger, but also the lower cirques remain, so it can be assumed that there is a broader spread of cirque floor heights. Besides, where glaciation is intense, new lower cirques are developed as the ELA descends, whereas many cirques remain well above it, constituting sources of valley glaciers; this further increases variability in cirque minimum 
elevations. This reasoning would be confirmed in the studied area, since cirque floors in the western part, where glaciations are considered to have been more extensive (Rabassa et al., 2000) (see Section 6.1.), cover an altitudinal interval somewhat higher than to the east: $80 \%$ of cirque floors in Martial Mountains and Vinciguerra Range are distributed between 953 and $613 \mathrm{~m}$ a.s.1 (340 $\mathrm{m}$ interval), whereas in eastern Sorondo Range they are concentrated between 743 and $440 \mathrm{~m}$ a.s.1 (303 $\mathrm{m}$ interval) (Table 6).

By contrast, in nearby Isla de los Estados, where glaciers that modelled its relief throughout the Pleistocene are supposed to have been of local origin, fed from the abundant existing cirques, and possibly by a local mountain ice cap, cirque floor elevation (mean value $=272 \mathrm{~m}$ a.s.1.) shows clear asymmetry in their distribution, in accordance with a stronger hemispheric insolation effect: average floor height of cirques present in the south coast is $50 \mathrm{~m}$ lower than average floor altitudes in the north coast (Ponce and Rabassa, 2012). Indeed, analysing cirque distribution data provided by these authors according to the aspect intervals used in this investigation, it is found that lowest cirques are exposed to SE (mean floor altitude: $198 \mathrm{~m}$ a.s.1.) and highest cirques face NE (316 m a.s.1.), reflecting even more visibly the insolation-based asymmetry in cirque floor elevation.

On the other hand, inner cirque floor altitudes in the analysed ranges are distributed in conformity with aspect: the lowest face SE, E and S sectors, which in turn are the dominant aspects, whereas the highest are $\mathrm{N}$-facing and $\mathrm{W}$-facing (Table 8). This trend supports the assumption that inner cirques were eroded by small ice masses strongly governed by an ELA near peaks (see Section 6.2.), which should have accentuated glacial asymmetry despite high topographic elevation, and is also in accordance with the context of generalized aridity and relatively cloudless skies proposed for the region during past glacial episodes.

\subsubsection{Influence of aspect on size and shape}

In the Fuegian Andes, largest cirques (in size and planar surface) are associated to S and SE aspects, whereas smaller cirques are found in slopes exposed to SW, W and NW (Table 7) (floor altitude of SWand $\mathrm{W}$-facing cirques are also among the highest; Table 7). A comparable situation is noticed in Isla de los Estados, where SE-facing cirques account for the greatest $\mathrm{L}, \mathrm{W}$ and $\mathrm{A}$, and NW- and NE-facing cirques show the lowest values for these attributes
(Ponce and Rabassa, 2012). Similarly, the converse tendency (i.e., larger cirques with poleward -eastward biased- orientations) has been recognized in other mountainous regions of Northern Hemisphere (e.g., Simoni, 2011; Křížek and Mida, 2013; Delmas et al., 2014). A possible explanation for these size distributions is that more expanded cirques are often associated with slope orientations that favour glacial mass balance, whereas smaller cirques tend to grow on flanks exposed to more intense solar radiation (Delmas et al., 2014). In the study area, the azimuthal distribution of cirque dimensions can therefore be understood as a result of differences in glacial residence time determined by hillside aspect, since in S and SE-facing slopes glaciers would have been the first to develop and the last to disappear during cold stages, in contrast to glaciers formed on slopes exposed to N and NW. On the other hand, cirque morphology varies sensibly as a function of aspect as well, with most longitudinally elongated cirques facing $\mathrm{S}$ and $\mathrm{SE}$, and widest cirques exposed to SW, NW and N (Table 7). In the same way, cirques in Isla de los Estados show the greatest L/W ratios in connection to SE and SW aspects (Ponce and Rabassa, 2012). Likewise, cirques with lowest degree of incision (highest $\mathrm{L} / \mathrm{H}$ values) in the Fuegian Andes are oriented to $\mathrm{S}, \mathrm{SE}$ and $\mathrm{E}$, whereas steeper cirques face NW, N and NE (Table 7). These tendencies are in agreement with greater glacial development in southeasterly oriented slopes, where glaciers would have extended downvalley beyond cirque limits (specially in Martial Mountains and Vinciguerra Range) comparatively for longer, increasing cirque backward erosion over widening and deepening. Inversely, in more insolated slopes, where cirque glaciers where relatively short-lived, processes of cirque lateral expansion would have been enhanced by longer-lasting periglacial and non-glacial conditions (Federici and Spagnolo, 2004; Delmas et al., 2015).

Nevertheless, aspect-related variation in cirque dimensions and morphology should not be considered as an exclusive function of climate, but structure would also have played a significant role. In that sense, persistent NW-SE/NNE-SSE strike lineaments, in the case of valley-head cirques, and (structurally controlled) SW-NE/SSW-NNE trending main ridgelines and (specially) W-E to NW-SE strike rock bedding (Fig. 5D), in the case of valley-side cirques, are considered to have enhanced to some extent size and lengthwise elongation (with associated incision 
lowering) in cirques with southeasterly aspects. Lineaments and bedding could also be responsible for the lesser expansion and longitudinal development of cirques exposed to SW. These evidences imply that allometric growth noticed in the studied cirques (Fig. 6) would be partly regulated by geological structure, as proposed by other authors (e.g., Delmas et al., 2015). Analogously, in Isla de los Estados, greatest area and L/W values found in SE-facing cirques also seems to be affected by the presence of NW-SE trending faults (Ponce and Rabassa, 2012).

Inner cirques tend to be larger when facing $\mathrm{SE}$ and $\mathrm{E}$, and smaller when exposed towards the $\mathrm{N}$ and NE (Table 8). Likewise, elongated shapes prevail in SE-, E- and S-facing cirques, but are also common in NW and W-facing cirques, and deeper (and generally more incised) cirques tend to face to E, SE, NW and $\mathrm{W}$ (Table 8 ). These distributions, especially regarding to climatically less favourable NW and W aspects, suggest strong structural (in particular bedding) control in inner cirques development. Moreover, inner cirques exhibit greater contrast in their aspect-derived size and shape variations compared to first-order cirques, in accordance with the more marginal glacial setting (i.e., greater glacial asymmetry) in which they were formed. This situation is also corroborated in Isla de los Estados (Ponce and Rabassa, 2012), where an analogous reasoning should be valid.

\section{Conclusions}

This study introduces cirque morphometry as a novel element of analysis for the reconstruction of glaciations in the Andes Range. The combined implementation of DEMs and GIS tools permitted a reliable, precise and quick extraction, quantification and systematization of morphometric attributes (of both cirques and relief), as well as the production of maps portraying this information.

An inventory mapping of glacial cirques was performed in the southwestern Fuegian Andes, in Tierra del Fuego, southern Argentina. Morphometric and distribution parameters of 251 first-order and 99 inner cirques were included in a GIS database for quantitative analysis, producing the following findings:

1. Cirques evidence allometric growth (i.e., floor deepening is surpassed by wall lengthening and widening as cirque expands), denoting the influence of diverse factors and processes in their formation.
Indeed, spatial variations in cirque morphometry along the studied ranges appear to suggest that their development was highly controlled by i) the activity of Beagle palaeoglacier, which would have regulated the dynamics of valley glaciers of lower hierarchy during glacial cycles (e.g., Rabassa et al., 1990b, 2000; Coronato 1995), and ii) to the W-E topographic gradient of the mountain chain. Both factors would have promoted the occurrence of slightly lengthwise elongated, smaller, deeper and more incised cirques towards the west (Martial Mountains and Vinciguerra Range), where slopes are generally steeper and glaciations are considered to have been more extensive throughout the Quaternary (e.g., Rabassa et al., 2000).

2. Prevalence of cirques facing S, SE and E (55\% of total set) reflects the combined incidence of climate and geological structure throughout their formation. In particular, "hemispheric insolation" effect would have been responsible for poleward orientation, whereas eastward deviation could be attributed to (i) more effective melting in afternoon hours, (ii) intense westerly humid winds and (iii) prevailing ridgeline/valley axis directions and bedrock structure, the latter comprised by the Beagle Channel transcurrent fault system and oblique strike-slip faults associated to it, as well as rock bedding. The apparent effect of solar radiation in cirque aspect is considered to indicate relatively cloud-free conditions and aridity during former cold episodes, and is in accordance with the findings of previous reports from the region (e.g., Unkel et al., 2008; Ponce et al., 2011a; Berman et al., 2016).

3. The absence of connection between cirque floor altitude and azimuth is interpreted as a consequence of extensive past glacial conditions in the area (i.e., mostly ice-sheet glaciation, with regional ELA far below mountain peaks), which would have permitted cirque glaciers to develop at relatively low elevations, even on climatically adverse (or less favourable) hillsides. This distribution pattern is likely influenced by the presence of younger generations of lower cirques, preferably on climatically favoured locations, formed throughout successive glacial episodes of different magnitudes.

4. Aspect-related variability in cirque morphometry is denoted by the greater concentration of large, 
lengthwise elongated and reduced height range cirques facing S and SE, and by smaller, wider and more incised cirques preferably associated with southwesterly to northwesterly orientations. This distribution is likely a result of differences in glacial residence time controlled by slope aspect, as well as structure, which seems to have accentuated these trends by means of promoting along-strike cirque erosion.

5. Formation of undersized, "inner" cirques within larger previous cirques is also common in the Fuegian Andes, and is possibly related to the erosive action of short-lived, small cirque-type glaciers, governed by temporal stabilization of the equilibrium line altitude (ELA) just above the compound host cirque floor. Development of inner cirques was apparently facilitated by bedrock structural variations, which would have determined their occurrence itself and their detailed position into container cirques. Likewise, structure (mainly rock bedding) is supposed to have played a key role in regulating inner cirque aspect and morphometry, reinforcing climate-related tendencies but also promoting cirque erosion in climatically less favourable azimuths. Unlike first-order, inner cirque floor altitude varies in correspondence with orientation, consistently with their development strongly ruled by the ELA and with the hypothesis of comparatively cloudless skies proposed for the region during glacial times.

\section{Acknowledgements}

We want to express our deep gratitude to Dr. I. Evans (Durham University, U.K.) for discussions that contributed to greatly enrich this work, and for sending useful articles by post. We are also grateful to M.P. Lira, D. Groch, L. Cabezas, P. Montero and M. Fehrmann for their assistance in field surveys. Oblique photographs of cirques were taken thanks to a helicopter flight as part of a research project by Dr. Brian Menounos (University of Northern British Columbia, Canada). We kindly appreciate very constructive suggestions and comments made by two anonymous reviewers, which significantly improved the manuscript. We also thank the thorough revisions made by the editor W. Vivallo. A substantial part of this work was supported by a CONICET grant, and CADIC (CONICET-Ushuaia) provided logistic resources for fieldwork and access to valuable bibliographic and cartographic information

\section{References}

Alonso, V. 1994. Análisis de los circos glaciares en las cabeceras de los ríos Narcea, Ibias y Sil. Cordillera Cantábrica (NW de la Península Ibérica). Cuaternario y Geomorfología 8 (1-2): 109-121.

Andrews, J.; Dugdale, R. 1971. Quaternary history of northern Cumberland peninsula, Baffin Island, NWT: Part V: Factors affecting corrie glacierization in Okoa Bay.Quaternary Research1 (4): 532-551.

Aniya, M.; Welch, R. 1981. Morphometric analyses of Antarctic cirques from photogrammetric measurements. Geografiska Annaler, Physical Geography, Series A 63 (1-2): 41-53.

Araos, J.M.; Le Roux, J.P.; Kaplan, M.R.; Spagnolo, M. 2018. Factors controlling alpine glaciations in the Sierra Baguales Mountain Range of southern Patagonia $\left(50^{\circ} \mathrm{S}\right)$, inferred from the morphometric analysis of glacial cirques.Andean Geology45 (3): 357-378. doi: 10.5027/andgeoV45n3-2974.

Barr, I.D.; Spagnolo, M. 2013. Palaeoglacial and palaeoclimatic conditions in the NW Pacific, as revealed by a morphometric analysis of cirques upon the Kamchatka Peninsula. Geomorphology 192: 15-29.

Barr, I.D.; Spagnolo, M. 2015. Glacial cirques as palaeoenvironmental indicators: Their potential and limitations. Earth-Science Reviews 151: 48-78.

Bathrellos, G.D.; Skilodimou, H.D.; Maroukian, H. 2014. The spatial distribution of Middle and Late Pleistocene cirques in Greece. Geografiska Annaler 96 (3): 323-338.

Bennett, M.R.; Glasser, N.F. 2011. Glacial geology: ice sheets and landforms. John Wiley and Sons: 400 p. London.

Berman, A.L.; Silvestri, G.E.; Tonello, M.S. 2016. Differences between Last Glacial Maximum and present-day temperature and precipitation in southern South America. Quaternary Science Reviews150: 221-233.

Borrello, A.V. 1969. Los geosinclinales de la Argentina. Anales de la Dirección Nacional de Geología y Minería 14: 1-188. Argentina

Bran, D.M.; Tassone, A.A.; Menichetti, M.; Cerredo, M.E.; Lozano, J.G.; Lodolo, E.; Vilas, J.F. 2018. Shallow architecture of Fuegian Andes lineaments based on Electrical Resistivity Tomography (ERT). Evidences of transverse extensional faulting in the central Beagle Channel area.Andean Geology45 (1): 1-34. doi: 10.5027/andgeoV45n1-3002.

Brook, M.S.; Kirkbride, M.P.; Brock, B.W. 2006. Cirque development in a steadily uplifting range: rates of 
erosion and long-term morphometric change in alpine cirques in the Ben Ohau Range, New Zealand. Earth Surface Processes and Landforms 31 (9): 1167-1175.

Caldenius, C. 1932. Las glaciaciones cuaternarias en la Patagonia y Tierra del Fuego.Geografiska Annaler14: 1-164.

Caminos, R. 1980. Cordillera fueguina. In Geología Regional Argentina. Academia Nacional de Ciencias de Córdoba 2: 1463-1501.

Caminos, R.; Haller, M.; Lapido, O.; Lizuain, A.; Page, R.; Ramos, V.A. 1981. Reconocimiento geológico de los Andes Fueguinos. Territorio Nacional de Tierra del Fuego. In Congreso Geológico Argentino, No. 8, Actas 3: 759-786. San Luis.

Clapperton, C.M. 1971. Evidence of cirque glaciation in the Falkland Islands. Journal of Glaciology 10 (58): 121-125.

Clapperton, C.; Sudgen, D.; Kaufman, D.; McCulloch, R. 1995. The last glaciation in Central Magellan Strait, Southernmost Chile. Quaternary Research 44: $133-148$

Compagnucci, R.H. 2011. Atmospheric circulation over Patagonia from the Jurassic to present: a review through proxy data and climatic modelling scenarios.Biological Journal of the Linnean Society103 (2): 229-249.

Coronato, A. 1990. Definición y alcance de la Última Glaciación Pleistocena (Glaciación Moat) en el Valle de Andorra, Tierra del Fuego. InCongreso Geológico Argentino, No. 11, Actas 1: 286-289. San Juan.

Coronato, A. 1993. La glaciacion Moat (Pleistoceno Superior) en los valles Pipo y Cañadón del Toro, Andes Fueguinos. In Congreso Geológico Argentino, No. 12, Actas 6: 40-47. Mendoza.

Coronato, A. 1995. The last Pleistocene glaciation in tributary valleys of the Beagle Channel, Southernmost South America. In Quaternary of South America and Antarctic Peninsula (Rabassa, J.; editor). Balkema Publishers 9: 173-182. Rotterdam.

Coronato, A. 1996. Desarrollo de circos en el sector sudoccidental de los Andes Fueguinos. In Congreso Geológico Argentino, No. 13, Actas 4: 347. Buenos Aires.

Coronato, A.; Salemme, M.; Rabassa, J. 1999. Palaeoenvironmental conditions during the early peopling of southernmost South America (Late Glacial-Early Holocene, 14-8 ka BP). Quaternary International 53: 77-92.

Coronato, A.; Meglioli, A.; Rabassa, J. 2004. Glaciations in the Magellan Straits and Tierra del Fuego, southernmost South America. Developments in Quaternary Sciences 2: $45-48$.
Coronato, A.; Seppälä, M.; Rabassa, J. 2005. Last Glaciation landforms in Lake Fagnano ice lobe, Tierra del Fuego, Southernmost Argentina. In International Conference on Geomorphology, No. 6, Actas: p. 22. Zaragoza.

Coronato, A.; Ponce, J.F.; Seppälä, M.; Rabassa, J. 2008. Englazamiento del valle del río Fuego durante el Pleistoceno tardío, Tierra del Fuego, Argentina. In Congreso Geológico Argentino, No. 17, Actas: 11941195. Jujuy.

Coronato, A.; Seppälä, M.; Ponce, F.; Rabassa, J. 2009. Glacial geomorphology of the Pleistocene Lake Fagnano ice lobe, Tierra del Fuego, southern South America. Geomorphology 112 (1-2): 67-81.

Crest, Y.; Delmas, M.; Braucher, R.; Gunnell, Y.; Calvet, M.; Aster Team. 2017. Cirques have growth spurts during deglacial and interglacial periods: Evidence from ${ }^{10} \mathrm{Be}$ and ${ }^{26} \mathrm{Al}$ nuclide inventories in the central and eastern Pyrenees. Geomorphology278: 60-77.

Cunningham, W.D. 1994. Uplifted ophiolitic rocks on Isla Gordon, southernmost Chile: implications for the closure history of the Rocas Verdes marginal basin and the tectonic evolution of the Beagle Channel region. Journal of South American Earth Sciences 7: 135-147.

Cunningham, W.D. 1995. Orogenesis at the southern tip of the Americas: the structural evolution of the Cordillera Darwin Metamorphic complex, southernmost Chile. Tectonophysics 244: 197-229.

Dalziel, I.W.D.; De Wit, M.J.; Palmer, K.F. 1974. Fossil marginal basin in the southern Andes. Nature 250: 291-294.

Damiani, A.V.; Pannuzi, L. 1987. La glaciazione pleistocenica nell"Appennino Laziale-Abruzzese. III nota: opportunità di precisazioni terminologiche, metodologiche ed introduzione di parametri morfometrici. Bollettino della Società Geologica Italiana 105: 75-96.

De Blasio, F.V. 2002. Note on simulating the size distribution of glacial cirques. Earth Surface Processes and Landforms 27 (1): 109-114.

Delmas, M.; Gunnell, Y.; Calvet, M. 2014. Environmental controls on alpine cirque size. Geomorphology 206: 318-329.

Delmas, M.; Gunnell, Y.; Calvet, M. 2015. A critical appraisal of allometric growth among alpine cirques based on multivariate statistics and spatial analysis. Geomorphology 228: 637-652.

Démangeot, J. 1965. Géomorphologie des Abruzzes adriatiques. In Mémoires et Documents (Dresch, J.; editor). Éditions du Centre National de la Recherche Scientifique: 260-263. Paris. 
Derbyshire, E.; Evans, I.S. 1976. The climatic factor in cirque variation. In Geomorphology and Climate (Derbyshire, E.; editor). John Wiley and Sons: 447494. Chichester.

Dudley, T.R.; Crow, G.E. 1983. A contribution to the flora and vegetation of Isla de los Estados (Staten Island), Tierra del Fuego, Argentina. American Geophysical Union, Antarctic Research Series, Terrestrial Biology 37: $1-26$

Ebrahimi, B.; Seif, A. 2017. Morphometric Properties of Glacial Cirques in Zagros Mountain, Iran.Geopersia7 (1): 131-151.

Embleton, C.; King, C.A.M. 1975. Glacial and periglacial geomorphology. Edward Arnold: 573 p. London.

Esteban, F.; Tassone, A.; Lodolo, E.; Menichetti, M.; Lippai, H.; Waldmann, N.; Darbo, A.; Baradello, L.; Vilas, J. 2014. Basement geometry and sediment thickness of Lago Fagnano (Tierra del Fuego). Andean Geology 41 (2): 293-313. doi: 10.5027/andgeoV41n2-a02.

Evans, I.S. 1972. General geomorphometry, derivatives of altitude, and descriptive statistics. In Spatial Analysis in Geomorphology (Chorley, R.J.; editor). Methuen: 17-90. London.

Evans, I.S. 1977. World-wide variations in the direction and concentration of cirque and glacier aspects. Geografiska Annaler 59 (3-4): 151-175.

Evans, I.S. 1994. Lithological and structural effects on forms of glacial erosion: cirques and lake basins. In Rock Weathering and Landform Evolution (Robinson, D.A.; Williams, R.B.G.; editors). John Wiley and Sons: 455-472. Chichester.

Evans, I.S. 1999. Was the cirque glaciation of Wales timetransgressive, or not? Annals of Glaciology 28: 33-39.

Evans, I.S. 2006a. Allometric development of glacial cirque form: Geological, relief and regional effects on the cirques of Wales. Geomorphology 80 (3-4): 245-266.

Evans, I.S. 2006b. Local aspect asymmetry of mountain glaciation: a global survey of consistency of favoured directions for glacier numbers and altitudes. Geomorphology 73 (1-2): 166-184.

Evans, I.S. 2010. Allometry, scaling and scale-specificity of cirques, landslides and other landforms. Transactions of the Japanese Geomorphological Union 31 (2): 133-153.

Evans, I.S. 2013. Major Scale Forms. In The Encyclopedia of Quaternary Science (Elias, S.A.; editor). Elsevier 1: 847-864. Amsterdam.

Evans, I.S.; Cox, N.J. 1974. Geomorphometry and the operational definition of cirques. Area 6: 150-153.
Evans, I.S.; Cox, N.J. 1995. The form of glacial cirques in the English Lake District, Cumbria. Zeitschrift für Geomorphologie 39 (2): 175-202.

Federici, P.R.; Spagnolo, M. 2004. Morphometric analysis on the size, shape and areal distribution of glacial cirques in the Maritime Alps (Western French-Italian Alps). Geografiska Annaler 86 (3): 235-248.

Fleming, K.; Johnston, P.; Zwartz, D.; Yokoyama, Y.; Lambeck, K.; Chappell, J. 1998. Refining the eustatic sea-level curve since the Last Glacial Maximum using far- and intermediate-field sites. Earth and Planetary Science Letters 163: 327-342.

Flint, R.F. 1957. Glacial and Pleistocene geology. John Wiley and Sons: 5 p. New York.

Foster, D.; Brocklehurst, S.H.; Gawthorpe, R.L. 2008. Small valley glaciers and the effectiveness of the glacial buzzsaw in the northern Basin and Range, USA. Geomorphology 102: 624-639.

García-Ruiz, J.M.; Gómez-Villar, A.; Ortigosa, L.; MartíBono, C. 2000. Morphometry of glacial cirques in the central Spanish Pyrenees. Geografiska Annaler 82 (4): 433-442.

Ghiglione, M.C. 2002. Diques clásticos asociados a deformación transcurrente en depósitos sinorogénicos del Mioceno inferior de la Cuenca Austral. Revista de la Asociación Geológica Argentina 57 (2): 103-118.

Ghiglione, M.C. 2017. El origen de los valles transversales de Patagonia y su relación con el levantamiento de la cordillera.Revista de la Asociación Geológica Argentina74 (1): 102-108.

Ghiglione, M.; Ramos, V.A. 2005. Progression of deformation and sedimentation in the southernmost Andes. Tectonophysics 405 (1-4): 25-46.

Ghiglione, M.C.; Cristallini, E.O. 2007. Have the southernmost Andes been curved since Late Cretaceous times? An analog test for the Patagonian Orocline. Geology 35: 13-16.

Glasser, N.F.; Jansson, K.N.; Harrison, S.; Kleman, J. 2008. The glacial geomorphology and Pleistocene history of South America between $38^{\circ} \mathrm{S}$ and $56^{\circ}$ S.Quaternary Science Reviews27 (3-4): 365-390.

Glasser, N.F.; Ghiglione, M.C. 2009. Structural, tectonic and glaciological controls on the evolution of fjord landscapes.Geomorphology105 (3-4): 291-302.

González, J.S.; Gutiérrez, R.B.G.; Gómez-Villar, A.; Vega, J.M.R. 2007. Evidencias de permafrost en el extremo sur de Los Andes (Tierra del Fuego) según el régimen térmico de los glaciares rocosos del Cerro Krund.Norba. Revista de geografía 12: 119-136. 
Gordon, J.E. 1977. Morphometry of cirques in the Kintail-Affric-Cannich area of northwest Scotland. Geografiska Annaler 59 (3-4): 177-194.

Gravelius, H. 1914. Grundrifi der gesamten Gewcisserkunde. Band I: Flufikunde. Compendium of Hydrology I. Rivers, in German: 179 p. Goschen, Berlin.

Hall, B.; Porter, C.; Denton, G.; Lowell, T.; Bromley, G. 2013. Extensive recession of Cordillera Darwin glaciers in southernmost South America during Heinrich Stadial 1.Quaternary Science Reviews 62: 49-55.

Hall, B.; Denton, G.; Lowell, T.; Bromley, G.; Putnam, A. 2017. Retreat of the Cordillera Darwin icefield during the Termination I. Cuadernos de Investigación Geográfica 43: 751-766.

Haynes, V.M. 1968. The influence of glacial erosion and rock structure on corries in Scotland. Geografiska Annaler 50 (4): 221-234.

Haynes, V.M. 1998. The morphological development of alpine valley heads in the Antarctic Peninsula. Earth Surface Processes and Landforms 23 (1): 53-67.

Heusser, C. 1989. Late Quaternary vegetation and climate of southern Tierra del Fuego.Quaternary Research31 (3): 396-406.

Heusser, C. 1994. Quaternary paleoecology of FuegoPatagonia.Revista do Instituto Geológico 15 (1-2): 7-26.

Hughes, P.D.; Gibbard, P.L.; Woodward, J.C. 2007. Geological controls on Pleistocene glaciation and cirque form in Greece. Geomorphology 88 (3-4): 242-253.

Ipsen, H.A.; Principato, S.M.; Grube, R.E.; Lee, J.F. 2018. Spatial analysis of cirques from three regions of Iceland: implications for cirque formation and palaeoclimate. Boreas47 (2): 565-576.

Isla, F.; Schnack, E. 1995. Submerged moraines offshore northern Tierra del Fuego, Argentina. Quaternary of South America and Antarctic Peninsula 9: 205-222.

Iturraspe, R.J. 2011. Glaciares de Tierra del Fuego. Editorial Duken: 182 p. Buenos Aires.

Iturraspe, R.; Urciuolo, A.; Strelin, J.; Iturraspe, R.; Camargo, S.; Pacheco, J. 2009. El retroceso del Glaciar Vinciguerra como respuesta al cambio climático en los Andes de Tierra del Fuego, Argentina.In Encuentro Internacional de Investigadores del Grupo de Trabajo de Nieves y Hielos de América Latina del PHI-UNESCO, No. 7, Actas: 61-76. Bogotá.

Izagirre, E.; Darvill, C.; Rada, C.; Aravena, J. 2018. Glacial geomorphology of the Marinelli and Pigafetta glaciers, Cordillera Darwin Icefield, southernmost Chile.Journal of Maps 14 (2): 269-281.
Jouzel, J.; Masson, V.; Cattani, O.; Falourd, S.; Stievenard, M.; Stenni, B.; Longinelli, A.; Johnsen, S.J.; Steffenssen, J.P.; Petit, J.R.; Schwander, J.; Souchez, R.; Barkov, N.I. 2001. A new $27 \mathrm{ky}$ high resolution East Antarctic climate record. Geophysical Research Letters 28 (16): 3199-3202.

Kaplan, M.; Fogwill, C.; Sugden, D.; Hulton, N.; Kubik, P.; Freeman, S. 2008. Southern Patagonian glacial chronology for the Last Glacial period and implications for Southern Ocean climate.Quaternary Science Reviews27 (3-4): 284-294.

Katz, H.R. 1972. Plate tectonics and orogenic belts in the South-East Pacific. Nature 237 (5354): 331

Kohn, M.J.; Spear, F.S.; Harrison, T.M.; Dalziel, I.W.D. 1995. ${ }^{40} \mathrm{Ar} /{ }^{39} \mathrm{Ar}$ geochronology and P-T-t paths from the Cordillera Darwin metamorphic complex, Tierra del Fuego, Chile. Journal of Metamorphic Geology 13 (2): 251-270.

Kranck, E.H. 1932. Geological Investigations in the Cordillera of Tierra del Fuego. Acta Geographica 4: 1-231.

Křížek, M.; Mida, P. 2013. The influence of aspect and altitude on the size, shape and spatial distribution of glacial cirques in the High Tatras (Slovakia, Poland). Geomorphology 198: 57-68.

Lodolo, E.; Menichetti, M.; Bartole, R.; Ben-Avraham, Z.; Tassone, A.; Lippai, H. 2003. Magallanes-Fagnano continental transform fault (Tierra del Fuego, southernmost South America). Tectonics 22 (6): 1076.

Lowe, J.J.; Rasmussen, S.O.; Björck, S.; Hoek, W.Z.; Steffensen, J.P.; Walker, M.J.C.; Yu, Z.C. 2008. Synchronisation of palaeoenvironmental events in the North Atlantic region during the Last Termination: a revised protocol recommended by the INTIMATE group. Quaternary Science Reviews 27 (1-2): 6-17.

Markgraf, V. 1993. Paleoenvironments and paleoclimates in Tierra del Fuego and southernmost Patagonia, South America. Palaeogeography, Palaeoclimatology, Palaeoecology102 (1-2): 53-68.

Maurer, M.; Menounos, B.; Clague, J.; Osborn, J. 2012. Patagonian glacier advances in concert with those in western North America. In Annual Fall Meeting of the American Geophysical Union, No. 45, Actas: C23D-0675. San Francisco.

McCulloch, R.; Bentley, M.; Purves, R.; Hulton, N.; Sugden, D.; Clapperton, C. 2000. Climatic inferences from glacial and palaeoecological evidence at the last glacial termination, southern South America.Journal of Quaternary Science: Published for the Quaternary Research Association15 (4): 409-417. 
McCulloch, R.; Fogwill, C.; Sudgen, D.; Bentley, M.; Kubik, P. 2005. Chronology of the Last Glaciation in Central Strait of Magellan and Bahía Inútil, Southernmost South America. Geografiska Annaler 87 (2): 289-312.

Meglioli, A. 1992. Glacial Geology of Southernmost Patagonia, the Strait of Magellan and Northern Tierra del Fuego. Ph.D. Thesis (Unpublished), University of Lehigh: 216 p. Bethlehem.

Meglioli, A.; Evenson, E.; Zeitler, P.; Rabassa, J. 1990. Cronología absoluta y relativa de los depósitos glaciarios de Tierra del Fuego, Argentina y Chile. In Congreso Geológico Argentino, No. 11, Actas 2: 457-460. San Juan.

Menichetti, M.; Lodolo, E.; Tassone, A. 2008. Structural geology of the Fuegian Andes and Magallanes foldand-thrust belt-Tierra del Fuego Island. Geologica Acta 6 (1): 19-42.

Menounos, B.; Clague, J.J.; Osborn, G.; Davis, P.T.; Ponce, F.; Goehring, B.; Maurer, M.; Rabassa, J.; Coronato, A.; Marr, R. 2013. Latest Pleistocene and Holocene glacier fluctuations in southernmost Tierra del Fuego, Argentina. Quaternary Science Reviews 77: 70-79.

Mercer, J.H. 1976. Glacial history of southernmost South America. Quaternary Research 6 (2): 125-166.

Mîndrescu, M.; Evans, I.S. 2014. Cirque form and development in Romania: Allometry and the buzzsaw hypothesis. Geomorphology 208: 117-136.

Mîndrescu, M.; Evans, I.S. 2017. Glacial Cirques in the Romanian Carpathians and Their Climatic Implications. In Landform Dynamics and Evolution in Romania (Rădoane, M.; Vespremeanu-Stroe, A.; editors). Springer: 197-213. Cham.

Mîndrescu, M.; Evans, I.S.; Cox, N.J. 2010. Climatic implications of cirque distribution in the Romanian Carpathians: Palaeowind directions during glacial periods. Journal of Quaternary Science 25 (6): 875-888.

Mitchell, S.G.; Montgomery, D.R. 2006. Influence of a glacial buzzsaw on the height and morphology of the Cascade Range in central Washington State, USA. Quaternary Research 65 (1): 96-107.

Mitchell, S.G.; Humphries, E.E. 2015. Glacial cirques and the relationship between equilibrium line altitudes and mountain range height. Geology 43 (1): 35-38.

Moreno, P.I.; Lowell, T.V.; Jacobson Jr, G.L.; Denton, G.H. 1999. Abrupt vegetation and climate changes during the last glacial maximum and the last Termination in the Chilean Lake District: a case study from Canal de la Puntilla ( $\left.41^{\circ} \mathrm{S}\right)$. Geografiska Annaler, Physical Geography, Series A 81 (2): 285-311.
Nelson, E.P. 1982. Post tectonic uplift of the Cordillera Darwin Orogenic Core Complex: evidence for fission track geochronology and closing temperature time relationships. Journal of the Geological Society of London 139: 755-761.

Olivero, E.B.; Martinioni, D.R. 2001. A review of the geology of the Argentinean Fuegian Andes. Jounal of South American Earth Sciences 14 (2): 175-188.

Olivero, E.B.; Malumián, N. 2008. Mesozoic-Cenozoic stratigraphy of the Fuegian Andes, Argentina. Geologica Acta: an international earth science journal 6 (1): 5-18.

Olyphant, G.A. 1977. Topoclimate and the depth of cirque erosion. Geografiska Annaler 59 (3-4): 209-213.

Olyphant, G.A. 1981. Allometry and cirque evolution. Geological Society of America Bulletin 92 (9): 679-685.

Orsi, A.H.; Whitworth III, T.; Nowlin Jr., W.D. 1995. On the meridional extent and fronts of the Antarctic Circumpolar Current.Deep Sea Research Part I: Oceanographic Research Papers 42 (5): 641-673.

Planas, X.; Ponsa, À.; Coronato, A.; Rabassa, J. 2002. Geomorphological evidence of different glacial stages in the Martial cirque, Fuegian Andes, southernmost South America. Quaternary International 87 (1): 19-27.

Ponce, J.; Rabassa, J. 2012. Geomorfología glaciar de la Isla de los Estados, Tierra del Fuego, Argentina. Revista de la Sociedad Geológica de España 25 (1-2): 67-84.

Ponce, J. F.; Rabassa, J.; Martínez, O. A. 2009. Morfometría y génesis de los fiordos de isla de los Estados, Tierra del Fuego. Revista de la Asociación Geológica Argentina 65 (4): 638-647.

Ponce, J.F.; Borromei, A.M.; Rabassa, J. 2011a. Evolución del paisaje y la vegetación durante el Cenozoico tardío en el extremo sureste del archipiélago fueguino y canal Beagle.Los cazadores-recolectores del extremo oriental fueguino. Arqueología de Península Mitre e Isla de los Estados: 31-64.

Ponce, J.F.; Rabassa, J.; Coronato, A.; Borromei, A.M. 2011b. Palaeogeographical evolution of the Atlantic coast of Pampa and Patagonia from the last glacial maximum to the Middle Holocene.Biological Journal of the Linnean Society103 (2): 363-379.

Ponce, J.F.; Menounos, B.; Fernadez, M.; Schaefer, J. 2015. Chronology and extent of autermost cirque moraines in the southernmost Fuegian Andes and Canadian Cordillera. In Congreso Argentino de Cuaternario y Geomorfología, No. 6, Actas: p. 225. Ushuaia. 
Porter, S.C. 1964. Composite pleistocene snow line of Olympic mountains and cascade range, Washington. Geological Society of America Bulletin75 (5): 477-482.

Porter, S.C. 1975. Equilibrium-line altitudes of late quaternary glaciers in the southern alps, New Zealand. Quaternary Research5: 27-47.

Porter, S.C. 1990. Character and ages of Pleistocene drifts in a transect across the Strait of Magellan.Quaternary of South America and Antarctic Peninsula7: 35-49.

Porter, S.C.; Clapperton, C.M.; Sudgen, D. 1992. Chronology and dynamics of deglaciation along and near the Strait of Magellan, southernmost South America. Sveriges Geologiska Undersökning 81: 233-239.

Puigdefábregas, J.; Del Barrio, G.; Iturraspe, R. 1988. Régimen térmico estacional de un ambiente montañoso en la Tierra del Fuego, con especial atención al límite superior del bosque. Pirineos 132: 37-48.

Rabassa, J. 2008. Late Cenozoic glaciations of Patagonia and Tierra del Fuego. In The Late Cenozoic of Patagonia and Tierra del Fuego. Developments in Quaternary Sciences (Rabassa, J.; van der Meer, J.J.; editors). Elsevier 11: 151-204. Amsterdam.

Rabassa, J.; Clapperton, C.M. 1990. Quaternary glaciations of the southern Andes.Quaternary Science Reviews9 (2-3): 153-174.

Rabassa, J.; Heusser, C.J.; Rutter, N. 1990a. Late Glacial and Holocene of Tierra del Fuego. Quaternary of South America and Antarctic Peninsula 7: 327-351.

Rabassa, J.; Serrat, D.; Marti, C.; Coronato, A. 1990b. El Tardiglacial en el Canal Beagle, Tierra del Fuego, Argentina y Chile. In Congreso Geológico Argentino, No. 11, Actas 1: 290-293. San Juan.

Rabassa, J.; Bujalesky, G.G.; Meglioli, A.; Coronato, A.; Gordillo, S.; Roig, C.; Salemme, M. 1992. The Quaternary of Tierra del Fuego, Argentina: the status of our knowledge.Sveriges Geologiska Undersökning series Ca. Research paper 81: 249-256.

Rabassa, J.; Coronato, A.; Roig, C.; Serrat, D. 1996. Geología Glacial de Bahía Sloggett, Tierra del Fuego, Argentina. In Geológico Argentino, No. 13, Actas 4: 329. Buenos Aires.

Rabassa, J.; Coronato, A.; Bujalesky, G.; Salemme, M.; Roig, C.; Meglioli, A.; Heusser, C.; Gordillo, S.; Roig, F.; Borromei, A.; Quattrocchio, M. 2000. Quaternary of Tierra del Fuego, southernmost South America: an updated review. Quaternary International 68: 217-240.

Rabassa, J.; Coronato, A.; Salemme, M. 2005. Chronology of the Late Cenozoic Patagonian glaciations and their correlation with biostratigraphic units of the Pampean region (Argentina). Journal of South American Earth Sciences 20 (1-2): 81-104.

Rabassa, J.; Coronato, A.; Heusser, C.; Juñent, F.R.; Borromei, A.; Roig, C.; Quattrocchio, M. 2006. The peatlands of Argentine Tierra del Fuego as a source for paleoclimatic and paleoenvironmental information. Developments in Earth Surface Processes 9: 129-144.

Ramos, V.A. 1999. Plate tectonic setting of the Andean Cordillera. Episodes 22: 183-190.

Rasmussen, S.O.; Andersen, K.K.; Svensson, A.M.; Steffensen, J.P.; Vinther, B.M.; Clausen, H.B.; Siggaard-Andersen, M.L.; Johnsen, S.J.; Larsen, L.B.; Dahl-Jensen, D.; Bigler, M.; Röthlisberger, R.; Fischer, H.; Goto-Azuma, K.; Hansson, M.E.; Ruth, U. 2006. A new Greenland ice core chronology for the last glacial termination. Journal of Geophysical Research: Atmospheres 111: D06102 doi: 10.1029/ 2005JD006079.

Rodbell, D.T.; Smith, J.A.; Mark, B.G. 2009. Glaciation in the Andes during the late Glacial and Holocene. Quaternary Science Reviews 28: 2165-2212.

Rosenqvist, A.; Shimada, M.; Ito, N.; Watanabe, M. 2007. ALOS PALSAR: A pathfinder mission for global-scale monitoring of the environment. IEEE Transactions on Geoscience and Remote Sensing 45 (11): 3307-3316.

Ruiz-Fernández, J.; Poblete-Piedrabuena, M.A.; SerranoMuela, M.P.; Martí-Bono, C.; García-Ruiz, J.M. 2009. Morphometry of glacial cirques in the Cantabrian Range (Northwest Spain). Zeitschrift für Geomorphologie 53 (1): 47-68.

Sanders, J.W.; Cuffey, K.M.; Moore, J.R.; MacGregor, K.R.; Kavanaugh, J.L. 2012. Periglacial weathering and headwall erosion in cirque glacier bergschrunds. Geology 40 (9): 779-782.

Sauchyn, D.J.; Cruden, D.M.; Hu, X.Q. 1998. Structural control of the morphometry of open rock basins, Kananaskis region, Canadian Rocky Mountains. Geomorphology 22 (3-4): 313-324.

Seif, A.; Ebrahimi, B. 2014. Combined use of GIS and experimental functions for the morphometric study of glacial cirques, Zardkuh Mountain, Iran. Quaternary International 353: 236-249.

Simoni, S. 2011. Typological and Morphometric Characteristics of the Glacial Cirques in Doamnei River basin (Făgăraş Massif). Forum Geografic 10 (1): 35-49.

Singer, B.S.; Ackert Jr., R.P.; Guillou, H. 2004. ${ }^{40} \mathrm{Ar} /{ }^{39} \mathrm{Ar}$ and $\mathrm{K}-\mathrm{Ar}$ chronology of Pleistocene glaciations in Patagonia.Geological Society of America Bulletin 116 (3-4): 434-450. 
Smalley Jr. R.; Kendrick, E.; Bevis, M.; Dalziel, I.; Taylor, F.; Lauría, E.; Barriga, R.; Casassa, G.; Olivero, E.; Piana, E. 2003. Geodetic determination of relative plate motion and crustal deformation across the ScotiaSouth America plate boundary in eastern Tierra del Fuego. Geochemistry, Geophysics, Geosystems 4 (9). doi: 10.1029/2002GC000446.

Steffanová, P.; Mentlík, P. 2007. Comparison of morphometric characteristics of cirques in the Bohemian Forest. Silva Gabreta 13 (3): 191-204.

Strelin, J.; Iturraspe, R. 2007. Recent evolution and mass balance of Cordón Martial glaciers, Cordillera Fueguina Oriental. Global and Planetary Change 59 (1-4): 17-26.

Strelin, J.; Casassa, G.; Rosqvist, G.; Holmlund, P. 2008. Holocene glaciations in the Ema Glacier valley, Monte Sarmiento Massif, Tierra del Fuego. Palaeogeography, Palaeoclimatology, Palaeoecology 260: 299-314.

Stuut, J.B.W.; Lamy, F. 2004. Climate variability at the southern boundaries of the Namib (southwestern Africa) and Atacama (northern Chile) coastal deserts during the last 120,000 yr.Quaternary Research62 (3): 301-309.

Thompson, W.G.; Goldstein, S.L. 2006. A radiometric calibration of the SPECMAP timescale.Quaternary Science Reviews25 (23-24): 3207-3215.

Ton-That, T.; Singer, B.; Mörner, N. A.; Rabassa, J. 1999. Datación de lavas basálticas por ${ }^{40} \mathrm{Ar} /{ }^{39} \mathrm{Ar}$ y geología glacial de la región del lago Buenos Aires, Provincia de Santa Cruz, Argentina.Revista de la Asociación Geológica Argentina54 (4): 333-352.

Torres-Carbonell, P.J.; Dimieri, L.V.; Olivero, E.B.; Bohoyo, F.; Galindo-Zaldívar, J. 2014. Structure and tectonic evolution of the Fuegian Andes (southernmost South America) in the framework of the Scotia Arc
development.Global and Planetary Change123: 174-188.

Trenhaile, A.S. 1976. Cirque morphometry in the Canadian Cordillera. Annals of the Association of American Geographers 66 (3): 451-462.

Tuhkanen, S. 1992. The climate of Tierra del Fuego from a vegetation geographical point of view and its ecoclimatic counterparts elsewhere. Acta Botanica Fennica 145: 1-64.

Unkel, I.; Björck, S.; Wohlfarth, B. 2008. Deglacial environmental changes on Isla de los Estados $\left(54.4^{\circ} \mathrm{S}\right)$, southeastern Tierra del Fuego.Quaternary Science Reviews27 (15): 1541-1554.

Valcárcel-Díaz, M.; Carrera-Gómez, P.; Coronato, A.; Castillo-Rodríguez, F.; Rabassa, J.; Pérez-Alberti, A. 2006. Cryogenic landforms in the Sierras de Alvear, Fuegian Andes, Subantarctic Argentina.Permafrost and Periglacial Processes 17 (4): 371-376.

Vega, J.M.R. 2004. El glaciar rocoso de Cerro Krund, Tierra del Fuego, Argentina.Cuadernos de Investigación Geográfica (30): 169-182.

Wainer, I.; Clauzet, G.; Ledru, M.P.; Brady, E.; OttoBliesner, B. 2005. Last Glacial Maximum in South America: paleoclimate proxies and model results. Geophysical Research Letters32 (8): NIL30-NIL33. doi: 10.1029/2004GL021244

Williams, L.D. 1975. The variation of corrie elevation and equilibrium line altitude with aspect in eastern Baffin Island, NWT, Canada.Arctic and Alpine Research: 169-181.

Zalazar, L.; Ferri, L.; Castro, M.; Gargantini, H.; Giménez, M.; Pitte, P.; Ruiz, L.; Masiokas, M.; Villalba, R. 2017. Glaciares de Argentina: Resultados Preliminares del Inventario Nacional de Glaciares. Revista de Glaciares y Ecosistemas de Montaña 2:13-22.

Manuscript received: June 14, 2018; revised/accepted: March 29, 2019; available online: January 31, 2020. 